Article

\title{
Interactive Impacts of Beneficial Microbes and Si-Zn Nanocomposite on Growth and Productivity of Soybean Subjected to Water Deficit under Salt-Affected Soil Conditions
}

\author{
Hany S. Osman ${ }^{1}\left(\mathbb{D}\right.$, Salah M. Gowayed ${ }^{2}{ }^{\circledR}$, Mohssen Elbagory ${ }^{3,4}$, Alaa El-Dein Omara ${ }^{4}(\mathbb{D}$, \\ Ahmed M. Abd El-Monem ${ }^{5}$ (D), Usama A. Abd El-Razek ${ }^{6}$ (D) and Emad M. Hafez ${ }^{7, *(D)}$ \\ 1 Department of Agricultural Botany, Faculty of Agriculture, Ain Shams University, Hadayek Shubra, \\ Cairo 11241, Egypt; hany_osman1@agr.asu.edu.eg \\ 2 Department of Botany, Faculty of Agriculture, Suez Canal University, Ismailia 41522, Egypt; \\ salahgowed@yahoo.com \\ 3 Department of Biology, Faculty of Science and Arts, King Khalid University, \\ Mohail Assir 61321, Saudi Arabia; mhmohammad@kku.edu.sa \\ 4 Department of Microbiology, Soils, Water and Environment Research Institute, Agricultural Research Center, \\ Giza 12112, Egypt; alaa.omara@yahoo.com \\ check for \\ updates \\ Citation: Osman, H.S.; Gowayed, \\ S.M.; Elbagory, M.; Omara, A.E.-D.; \\ El-Monem, A.M.A.; Abd El-Razek, \\ U.A.; Hafez, E.M. Interactive Impacts \\ 5 Department of Agronomy, Faculty of Agriculture, New Valley University, New Valley, \\ Elkharrga 72511, Egypt; abdelmonem07@agr.nvu.edu.eg \\ 6 Agronomy Department, Faculty of Agriculture, Tanta University, Tanta 31527, Egypt; \\ usama.eldesouky@agr.tanta.edu.eg \\ 7 Department of Agronomy, Faculty of Agriculture, Kafrelsheikh University, Kafr El-Sheikh 33516, Egypt \\ * Correspondence: emadhafez2012@agr.kfs.edu.eg
} of Beneficial Microbes and Si-Zn Nanocomposite on Growth and Productivity of Soybean Subjected to Water Deficit under Salt-Affected Soil Conditions. Plants 2021, 10, 1396. https://doi.org/10.3390/ plants10071396

Academic Editors:

Mirza Hasanuzzaman, Raffaella

Maria Balestrini, Chrystalla Antoniou and Vasileios Fotopoulos

Received: 20 May 2021

Accepted: 6 July 2021

Published: 8 July 2021

Publisher's Note: MDPI stays neutral with regard to jurisdictional claims in published maps and institutional affiliations.

Copyright: (c) 2021 by the authors. Licensee MDPI, Basel, Switzerland. This article is an open access article distributed under the terms and conditions of the Creative Commons Attribution (CC BY) license (https:// creativecommons.org/licenses/by/ $4.0 /)$.

\begin{abstract}
Water stress or soil salinity is considered the major environmental factor affecting plant growth. When both challenges are present, the soil becomes infertile, limiting plant productivity. In this work a field experiment was conducted during the summer 2019 and 2020 seasons to evaluate whether plant growth-promoting microbes (PGPMs) and nanoparticles ( $\mathrm{Si}-\mathrm{ZnNPs}$ ) have the potential to maintain soybean growth, productivity, and seed quality under different watering intervals (every $11\left(\mathrm{IW}_{0}\right), 15\left(\mathrm{IW}_{1}\right)$ and 19 (IW 2$)$ days) in salt-affected soil. The most extended watering intervals (IW and $\mathrm{IW}_{2}$ ) caused significant increases in $\mathrm{Na}^{+}$content, and oxidative damage indicators (malondialdehyde (MDA) and electrolyte leakage (EL\%)), which led to significant reductions in soybean relative water content (RWC), stomatal conductance, leaf $\mathrm{K}^{+}$, photosynthetic pigments, soluble protein. Subsequently reduced the vegetative growth (root length, nodules dry weight, and total leaves area) and seeds yield. However, there was an enhancement in the antioxidants defense system (enzymatic and non-enzymatic antioxidant). The individual application of PGPMs or Si-ZnNPs significantly improved leaf $\mathrm{K}^{+}$content, photosynthetic pigments, RWC, stomatal conductance, total soluble sugars (TSS), CAT, POD, SOD, number of pods plant ${ }^{-1}$, and seed yield through decreasing the leaf $\mathrm{Na}^{+}$ content, MDA, and EL\%. The combined application of PGPMs and Si-ZnNPs minimized the adverse impact of water stress and soil salinity by maximizing the root length, heavier nodules dry weight, leaves area, TSS and the activity of antioxidant enzymes, which resulted in higher soybean growth and productivity, which suggests their use under harsh growing conditions.
\end{abstract}

Keywords: Glycine max; PGPR; nano-minerals; osmolyte; photosynthesis; plant water relations; antioxidant defense system; seed quality

\section{Introduction}

Globally, salt-affected soils are one of the most serious ecological problems, particularly in arid and semi-arid regions [1], and are expected to exacerbate further in the coming era, as they have become a primary factor in reducing field crop productivity and negatively impacting sustainable agricultural development [2]. Around 25\% of arable agricultural 
soils worldwide are affected by salt stress, and an estimated 1.5 million hectares are lost to production each year as a result of salt stress [3]. Soil salinization has a number of unintended consequences, including a decrease in the ability of plant roots to absorb water and nutrients [4,5], a decrease in morpho-physiological characteristics, and degradation of chlorophylls as a result of hyperosmotic and hyper-ionic effects resulting in oxidative damage [6-9]. Drought or deficit irrigation is another major adverse abiotic stress that affects plant development. Water stress, like salinity stress, simulates physiological dehydration and results in low water potential and osmotic stress [10]. Water stress has a detrimental effect on plant development and yield, resulting in a cascade of morphological, biochemical, and physiological disturbances [11,12], particularly in arid and semi-arid zones, where evapotranspiration exceeds the annual precipitation, which results in an increase in salt levels in the near-surface soil layer [13]. As a result, water stress interacts with soil salinity, both of which have a negative impact on plant performance, and development, resulting in loss the plant yield and quality [14].

The Leguminosae is the second largest plant family in the agriculture sector, and are considered as the most important source of vegetable protein in human diets and livestock forages, as well as ensuring long-term sustainable agriculture [15]. Soybean (Glycine max L.) is the most important cultivated legume cash crop rich in protein, carbohydrates, mineral nutrients, and oil [16]. Unlike the majority of legume crops, which are considered plants sensitive to osmotic stress, soybean has a little higher tolerance level which is regarded as a moderate sensitivity to salt stress $[17,18]$. The soil salinity threshold for soybean yield is $5.0 \mathrm{dS} \mathrm{m}^{-1}$, so a $50 \%$ reduction in soybean yield was observed with exposure to $7.5 \mathrm{dS} \mathrm{m}^{-1}$ soil salinity [18]. In contrast, drought stress could trigger a $24: 50 \%$ reduction in the soybean seed yield [19]. Throughout the vegetative growth, numerous amino acids and sugars are promptly synthesized and transported during the reproductive growth to seeds. Thus, the development of soybean needs good agronomic practices for the increment of seed crop as the flowering and seed filling stages are the most drought-susceptible stages [20].

Remarkable studies have been conducted on the growth and productivity of crops grown under drought and salinity stress, and significant applications have been evaluated for their ability in improving the growth and development of field crops cultivated under drought and salinity stresses, which consider as an innovative approach for sustainable agriculture [21-25]. Beneficial microorganisms in the rhizosphere have positive effects on plant growth and development. Mycorrhizal fungi, $\mathrm{N}_{2}$-fixing bacteria, and plant growth-promoting rhizobacteria (PGPR) are the most rhizosphere species that have been extensively studied for their beneficial effects on plant growth and served as plant growth-promoting microbes (PGPMs) [26], which could limit the adverse impact of environmental stressors as well as are eco-friendly and low cost-efficient applications [27]. PGPMs are considered one of the important keys to solving environmental problems such as drought and salinity, which adverse osmotic stress and stimulate plant growth and development [28]. Application of PGPM could alleviate the negative impacts of abiotic stresses through the production of phytohormones, i.e., auxins, gibberellins, cytokinins, abscisic acid, as well as jasmonic acid, and salicylic acid, which has the ability to stimulate the systemic tolerance, in addition to producing exopolysaccharides (EPS) [28,29]. The synthesized phytohormones by PGPMs promote plant cell division and root length, which indirectly enhance the water absorption ratio and regulate the stomatal closure, osmolytes content, and improving activity of antioxidant enzymes, which cause an inhibition in the stress-related oxidative damages resulting in declined leaf transpiration which positively affecting seed production in plants subjected to different abiotic stresses [30].

Bradyrhizobium japonicum is a highly efficient nitrogen fixer that forms a symbiotic relationship with soybean. Under various environmental conditions, isolates from stressaffected soil are the most successful PGPMs [31]. Soybean co-inoculation with PGPMs and its natural symbiont (B. japonicum) altered plant growth parameters and markedly increased nodulation, and significantly increase the fixed- $\mathrm{N}_{2}$ amounts, which increase grain yield, thereby reducing reliance on fertilization with inorganic $\mathrm{N}[32,33]$. Trichoderma 
is a genus present in many habitats, where certain strains have the potential to mitigate the severity of plant diseases by inhibiting the pathogens due to their high antagonistic potential [34]. When plants inoculated with Trichoderma harzianum are exposed to abiotic stress, T. harzianum alters the biosynthesis of plant secondary metabolites such as phytohormones and the osmolytes, which increases photosynthetic pigments, proline, soluble proteins, and vegetative growth, in addition to increasing the level of phenols, flavonoids, and IAA in the stressed plants [35,36].

A large number of proteins are contained or bound to $\mathrm{Zn}$, which is the only metal used in all six enzyme groups, including oxidoreductases, transferases, hydrolases, lyases, isomerases, and ligases [37]. Plants grown under salinity or drought stress benefit from the application of $\mathrm{Zn}$ by increasing their tolerance level, which is reflected in enhanced plant growth, chlorophyll content, and biomass in rice [38], decreased proportion of aborted seeds per pod, and increased the yield quantity of pea [39], upregulation of the activity of antioxidant enzymes, and accumulation of osmolytes [40]. Silicon ( $\mathrm{Si}$ ) is a critical component of crop production, especially in minimizing the negative impacts of oxidative, salinity, and drought stresses [41,42]. Treating plants with nano-Si enhances the plant nutrition status by limiting the transportation of $\mathrm{Na}^{+}$ions from roots to leaves and by increasing the level of $\mathrm{K}^{+}$ions in leaves under soil salinity conditions [43]. It was recently discovered that plants treated with nanominerals as nutrients and stimulants showed improved physiological and biochemical attributes, decreased oxidative damage, stimulated water and nutrient uptake and improved plant growth, resulting in increased seed yields [44].

Previous studies have produced insufficiently reliable outcomes. There is an urgent need to investigate environmentally sustainable applications to improve soybean production under stress condition. To fulfil this goal, this study aimed to quantify the effects of foliar spray with nanominerals (Si-Zn) in combination with the soil application of PGPMs on the vegetative growth, plant water relation, antioxidant defense system, and seed yield of soybean plants cultivated in salt-affected soil under different watering intervals.

\section{Results}

A field experiment was conducted on soybean plants grown in salt-affected soil under different irrigation intervals $\left(\mathbf{I W}_{\mathbf{0}} ; 11\right.$ days, $\mathbf{I W}_{\mathbf{1}} ; \mathbf{1 5}$ days, and $\mathbf{I W}_{\mathbf{2}} ; 19$ days) during two successive summer seasons (2019 and 2020). In contrast to well-watered soybean plants, all of the studied parameters were markedly reduced as a result of exposure to more extended irrigation periods under salt-affected soil. As a result of individual application of plant growth-promoting microbes (PGPMs) or nanocomposite ( $\mathrm{Si}+\mathrm{Zn}$ ) and their combination, various variables such as exchangeable $\mathrm{Na}$ in the soil, plant biochemical and physiological characteristics have positively influenced the yield and related traits as well as seed quality. Regardless of irrigation intervals, the combined application of PGPMs and Si-ZnNPs resulted in a greater increase in all studied parameters compared to untreated plants (control).

\subsection{Exchangeable Sodium Percentage (ESP)}

Comparing to well-watered plants $\left(\mathrm{IW}_{0}\right)$, the longer watering intervals $\left(\mathrm{IW}_{1}\right.$ and $\mathrm{IW}_{2}$ ) significantly increased the exchangeable Na percentage (ESP) in salt-affected soil (Figure 1A). On the other hand, ESP decreased marginally when Si-ZnNPs was applied on foliage, and it decreased even further when PGPMs were applied to the soil. In salt-affected soil, the greatest reduction in ESP was achieved by using a combination of PGPMs and Si-ZnNPs in both seasons and at various irrigation water intervals (Figure 1A). In both seasons, exposing soybean plants to a combination of PGPMs and Si-ZnNPs in IW 1 restored the ESP in the soil as its percentage in the control treatment of the well watering condition $\left(\mathrm{IW}_{0}\right)$. Similar results were obtained for the coupled treatment in $\mathrm{IW}_{2}$ compared to the control treatment under 15 days of interval watering $\left(\mathrm{IW}_{1}\right)$. 


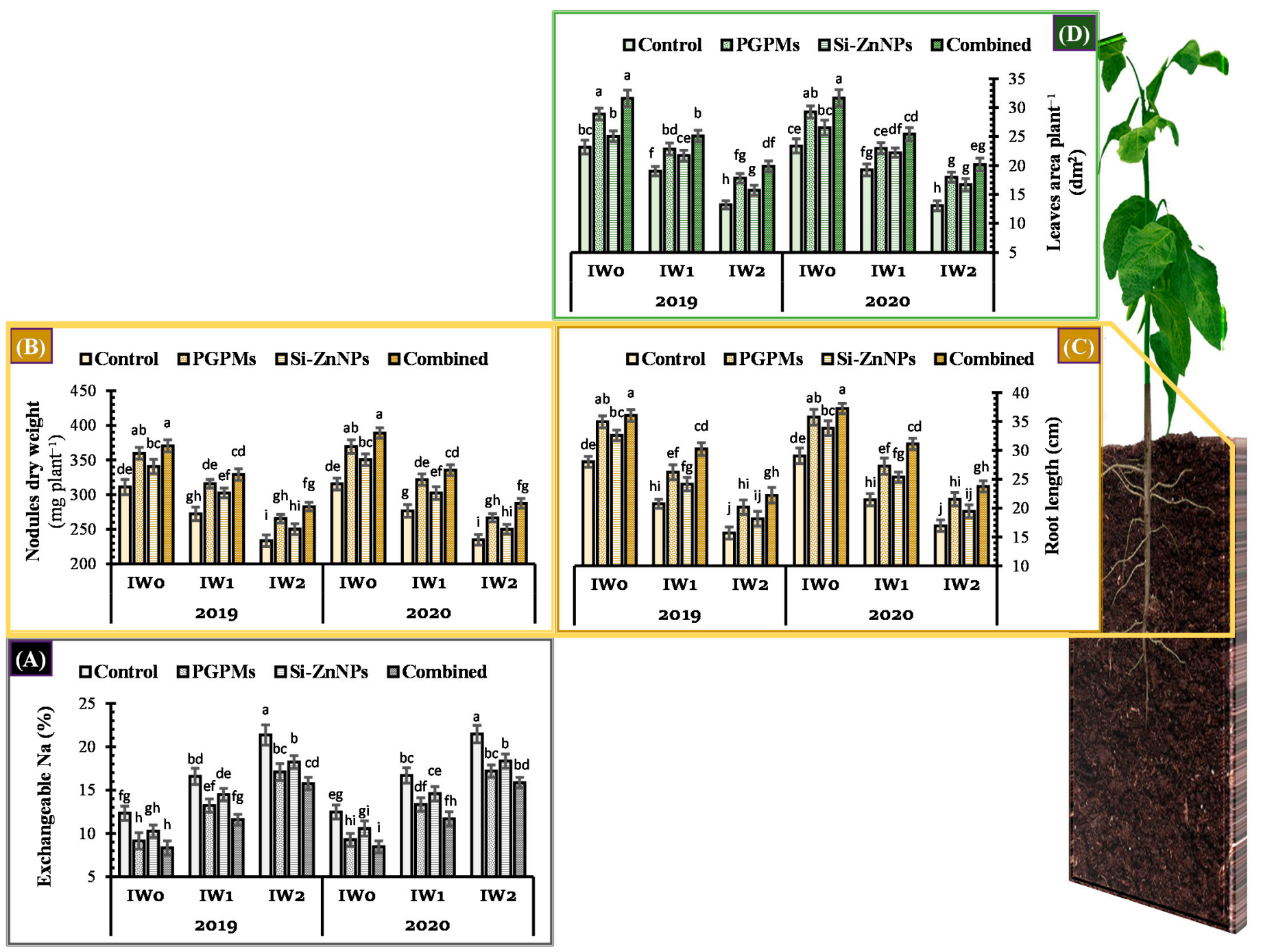

Figure 1. Influence of application of PGPMs, Si-ZnNPs and their combination on (A) the percentage of exchangeable Na in the soil, and (B) nodules dry weight, (C) root length, and (D) total leaves area of soybean plant grown in salt-affected soil with different levels of watering intervals ( $\mathbf{I W}_{\mathbf{0}} ; 11$ days, $\mathbf{I W}_{\mathbf{1}} ; 15$ days, and $\mathbf{I W}_{\mathbf{2}} ; 19$ days) during the successive 2019 and 2020 growing seasons. The data presented as means \pm SD. Means labeled with the same lower-case letter are not significantly different according to Duncan's Multiple Range Test.

\subsection{Vegetative Growth Characteristics}

\subsubsection{Root Length and Nodules Dry Weight}

Longer irrigation cycles $\left(\mathrm{IW}_{1}\right.$ and $\mathrm{IW}_{2}$ ) significantly decreased root length and nodules dry weight of soybean plants grown in salt-affected soil relative to well water plants $\left(\mathrm{IW}_{0}\right)$ (Figure 1B,C). However, foliar application of Si-ZnNPs resulted in a slight significant increase in root length and nodule dry weight, while application of PGPMs resulted in a more substantial increase. The highest increase was observed when combined PGPMs and Si-ZnNPs were applied in both seasons, regardless of irrigation regime. According to the data provided in Figure 1, soybean plants subjected to $\mathrm{IW}_{1}$ treatment (irrigation every 15 days) with the application of combined PGPMs and Si-ZnNPs had longer roots and heavier nodules than control plants in $\mathrm{IW}_{0}$ (irrigation every 11 days). Similarly, soybean plants that received the $\mathrm{IW}_{2}$ treatment (irrigation every 19 days) with mixed PGPMs and Si-ZnNPs application had longer roots and heavier nodules than control plants in the $\mathrm{IW}_{1}$ treatment (irrigation every 15 days). Furthermore, the individual application of PGPMs 
surpassed Si-ZnNPs application in terms of root length and nodule dry weight in both seasons (Figure 1B,C).

\subsubsection{Total Leaves Area}

Irrigation every 15 and 19 days significantly reduced the leaves area of soybean plants. However, under recommended irrigation $\left(\mathrm{IW}_{0}\right)$, the foliar application of Si-ZnNPs recorded only a $7.9 \%$ increase in leaves area plant ${ }^{-1}$. In contrast, individual PGPMs application presented a higher effect, which increased the leaves area by $24.6 \%$ over control (Figure 1D). The highest increase percentage (36.3\%) observed with the combined application PGPMs and Si-ZnNPs under $\mathrm{IW}_{0}$ treatment. Soybean plants irrigated every 15 days with a combination of PGPMs and Si-ZnNPs had a tiny higher leaves area plant ${ }^{-1}$ $(8.3 \%)$ over control plants that irrigated every 11 days. Similarly, soybean plants watering every 19 days with mixed PGPMs and Si-ZnNPs application had only a 4.5\% increase in the leaves area plant ${ }^{-1}$ over control plants that irrigated every 15 days (Figure 1D).

\subsection{Concentration of Sodium and Potassium in Leaves}

As anticipated in salinized soils, longer watering intervals $\left(\mathrm{IW}_{1}\right.$ and $\left.\mathrm{IW}_{2}\right)$ had a detrimental effect on the ion balance (low $\mathrm{K}^{+}$and high $\mathrm{Na}^{+}$) in the leaves of soybean plants, resulting in decreased efficiency when compared to well water treatment $\left(\mathrm{IW}_{0}\right)$ (Figure 2). Both $\mathrm{IW}_{1}$ and $\mathrm{IW}_{2}$ treatment reduced the content of $\mathrm{K}$ in leaves by $42.2 \%$ and $81.9 \%$ compared to $\mathrm{IW}_{0}$ control, meanwhile the content of $\mathrm{Na}$ increased by $46.1 \%$ and $101.8 \%$ over $\mathrm{IW}_{0}$ control treatment. Individual applications of PGPMs or Si-ZnNPs and their combination significantly affected $\mathrm{K}^{+}$and $\mathrm{Na}^{+}$content in the soybean leaves in salt-affected soil, irrespective of the watering interval applied $\left(\mathrm{IW}_{0}, \mathrm{IW}_{1}\right.$, and $\left.\mathrm{IW}_{2}\right)$. The combined application reduced the $\mathrm{Na}^{+}$levels by $64.8 \%, 39.4 \%$, and $35.4 \%$ compared to the control of each treatment $\left(\mathrm{IW}_{0}, \mathrm{IW}_{1}\right.$, and $\left.\mathrm{IW}_{2}\right)$. The efficiency of individual application Si-ZnNPs was higher than PGPMs on increasing $\mathrm{K}^{+}$content and decreasing $\mathrm{Na}^{+}$content in the leaves in both seasons compared to control plants. More significant increases in the leaf content of $\mathrm{K}^{+}$were discovered as a result of the co-application (PGPMs and Si-ZnNPs), which increased by $74.5 \%, 92.7 \%$, and $276.7 \%$ more than the control subjected to water stress at $\mathrm{IW}_{0}, \mathrm{IW}_{1}$, and $\mathrm{IW}_{2}$. Furthermore, soybean plants undergoing $\mathrm{IW}_{1}$ co-application treatment $\mathrm{Si}-\mathrm{ZnNPs}$ and PGPMs increased $\mathrm{K}^{+}$content by $11.4 \%$ and decreased $\mathrm{Na}^{+}$content by $11.5 \%$ than control plants in $\mathrm{IW}_{0}$ (Figure 2 ).

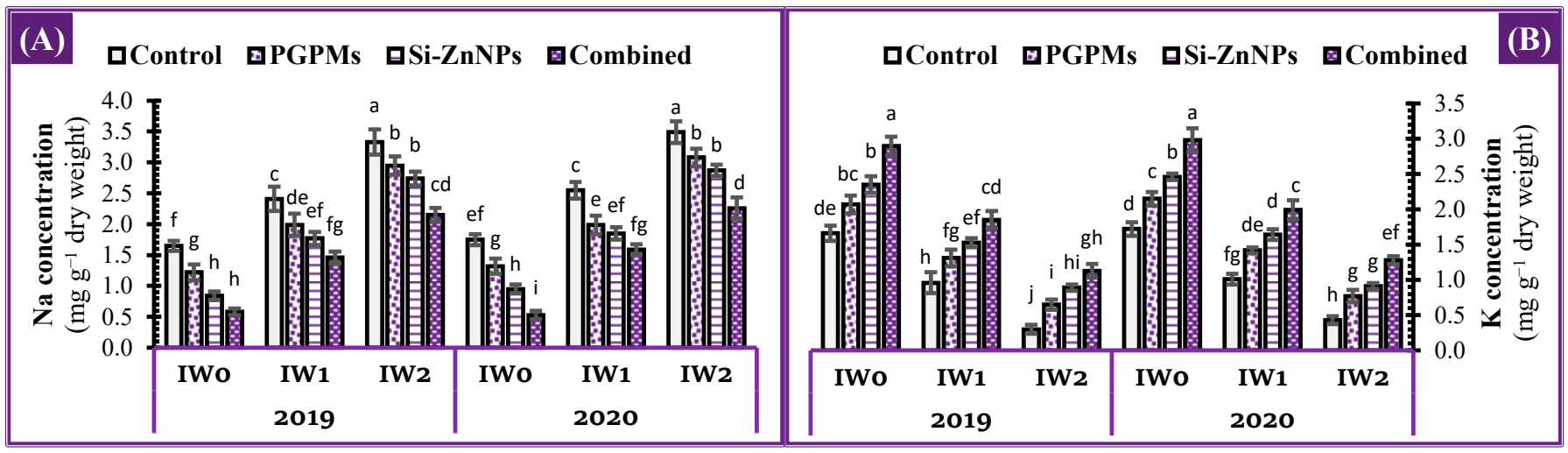

Figure 2. Influence of application of PGPMs, Si-ZnNPs and their combination on the concentration of $(\mathbf{A})$ sodium $\left(\mathrm{Na}^{+}\right)$, and $(\mathbf{B})$ potassium $\left(\mathrm{K}^{+}\right)$in the leaves of soybean plant grown in salt-affected soil with different levels of watering intervals $\left(\mathbf{I W}_{\mathbf{0}} ; 11\right.$ days, $\mathbf{I W}_{\mathbf{1}} ; 15$ days, and $\mathbf{I W}_{\mathbf{2}} ; 19$ days) during the successive 2019 and 2020 growing seasons. The data presented as means \pm SD. Means labeled with the same lower-case letter are not significantly different according to Duncan's Multiple Range Test. 


\subsection{Photosynthetic Pigments Concentration}

Concentrations of photosynthetic pigments (chlorophyll and carotenoids) in the leaves of soybean plant were negatively affected by the interaction of longer intervals watering $\left(\mathrm{IW}_{1}\right.$ and $\left.\mathrm{IW}_{2}\right)$ and the salt-affected soil compared to well water treatment $\left(\mathrm{IW}_{0}\right)$, which markedly decreased the chlorophyll content by $27.3 \%$ and $64.0 \%$ in the control of $\mathrm{IW}_{1}$ and $\mathrm{IW}_{2}$ comparing to its content in $\mathrm{IW}_{0}$ (Figure 3). Furthermore, the addition of PGPMs or Si-ZnNPs alone or in combination reduced the adverse effects of $\mathrm{IW}_{1}$ and $\mathrm{IW}_{2}$ and improved the content of total chlorophyll and carotenoids. Under deficit water treatments $\left(\mathrm{IW}_{1}\right.$ and $\left.\mathrm{IW}_{2}\right)$, plants inoculated with B. japonicum and T. harzianum in combination with nanoparticles $(\mathrm{Si}+\mathrm{Zn}$ ) showed the greatest increase in total chlorophyll $(79.8 \%$, and $150.0 \%)$ and carotenoids ( $155.0 \%$, and $257.1 \%$ ) over their own control. In contrast, comparing the combined treatment under $\mathrm{IW}_{1}$ and $\mathrm{IW}_{2}$ with the control of $\mathrm{IW}_{0}$, under interval watering every 15 days, the chlorophyll and carotenoids content increased by $30.7 \%$ and $13.3 \%$, respectively, while under the longest interval watering $\left(\mathrm{IW}_{2}\right)$, both pigments decreased by $10.0 \%$ and $44.4 \%$, respectively. The minimum increment over the control treatment was noted for PGPMs sole application, while nanoparticles ( $\mathrm{Si}+\mathrm{Zn}$ ) application was more effective than PGPMs regardless of irrigation intervals (Figure 3).

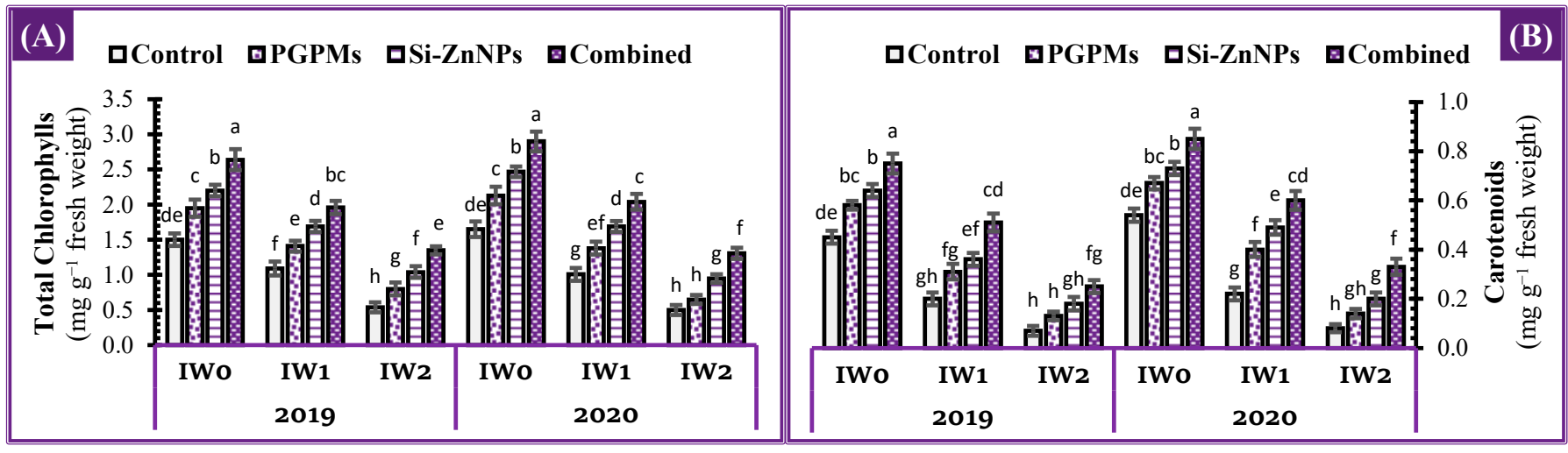

Figure 3. Influence of application of PGPMs, Si-ZnNPs and their combination on the concentration of (A) total chlorophylls, and (B) carotenoids in the leaves of soybean plant grown in salt-affected soil with different levels of watering intervals $\left(\mathbf{I W}_{\mathbf{0}}\right.$; 11 days, $\mathbf{I W}_{\mathbf{1}} ; 15$ days, and $\mathbf{I W}_{\mathbf{2}} ; 19$ days) during the successive 2019 and 2020 growing seasons. The data presented as means \pm SD. Means labeled with the same lower-case letter are not significantly different according to Duncan's Multiple Range Test.

\subsection{Osmoprotectants}

Changes in the biochemical parameters that have an osmo-protective role in the leaves of soybean plants cultivated under different irrigation intervals, i.e., total soluble sugars (TSS), proline, free amino acid (FAA), and soluble protein (SP), are presented in Figure 4. The prolonged intervals of watering $\left(\mathrm{IW}_{1}\right.$ and $\left.\mathrm{IW}_{2}\right)$ resulted in substantial increases in the osmolytes content (TSS [171.2\%, and 309.5\%], FAA [33.0\%, and 62.2\%], and proline [104.7\%, and $138.7 \%]$ ) of soybean leaves, whereas significant decreases in the soluble proteins $(34.2 \%$, and $54.2 \%$ ) were observed under the same watering conditions compared to controls of well-watered irrigation $\left(\mathrm{IW}_{0}\right)$. In contrast, sole application of PGPMs under $\mathrm{IW}_{0}, \mathrm{IW}_{1}$, and $\mathrm{IW}_{2}$ resulted in a gradual decrease in leaf proline and FAA content, while gradual increases in SP and TSS were observed. Whereas the individual application of Si-ZnNPs under $\mathrm{IW}_{0}, \mathrm{IW}_{1}$, and $\mathrm{IW}_{2}$ lowered the content of proline, FAA, and TSS than PGPMs application, while a higher increase in SP content was observed comparing to PGPMs sole application. Treating soybean plants with the co-application of PGPMs and Si-ZnNPs under $\mathrm{IW}_{0}, \mathrm{IW}_{1}$ and $\mathrm{IW}_{2}$ showed the greatest decrease in the content of proline $(40.3 \%, 32.5 \%$, and $23.6 \%)$, FAA $(45.3 \%, 32.2 \%$, and $22.5 \%)$, as well as the greatest increase in the content of TSS $(213.6 \%, 141.9 \%$, and $65.0 \%)$ and SP $(46.2 \%, 74.4 \%$, and $73.7 \%)$ comparing to their controls. 
In comparison between the combined application (PGPMs and (Si-ZnNPs) under longer watering intervals and the control of well irrigation treatment $\left(\mathrm{IW}_{0}\right)$, it revealed that TSS increased by 6 -fold its content under both $\mathrm{IW}_{1}$ and $\mathrm{IW}_{2}$ conditions (Figure 4).

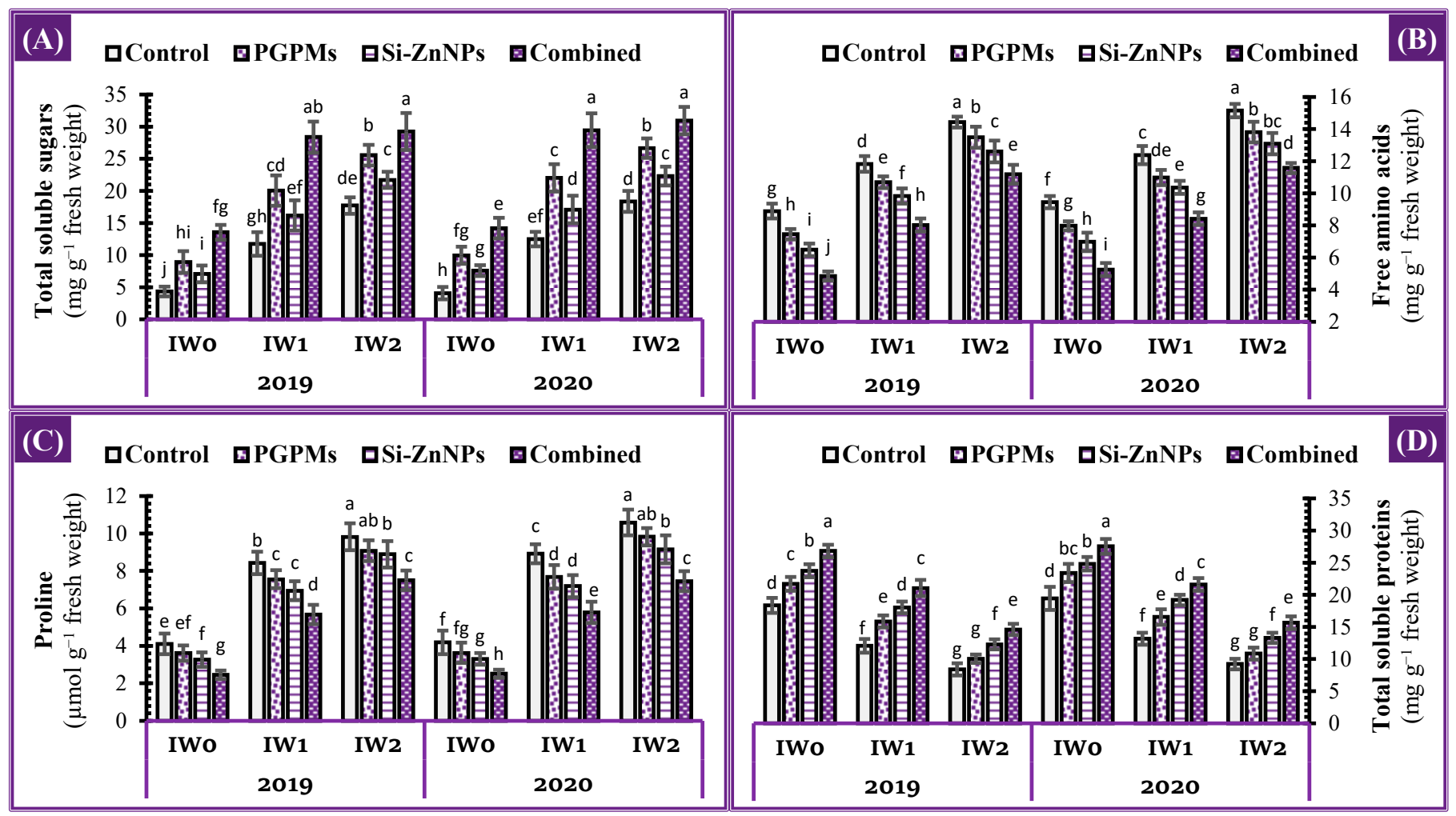

Figure 4. Influence of application of PGPMs, Si-ZnNPs and their combination on the concentration of (A) total soluble sugar, (B) free amino acids, (C) proline, and (D) total soluble proteins in the leaves of soybean plant grown in salt-affected soil with different levels of watering intervals $\left(\mathbf{I W}_{\mathbf{0}} ; 11\right.$ days, $\mathbf{I W}_{\mathbf{1}} ; 15$ days, and $\mathbf{I W}_{\mathbf{2}} ; 19$ days) during the successive 2019 and 2020 growing seasons. The data presented as means \pm SD. Means labeled with the same lower-case letter are not significantly different according to Duncan's Multiple Range Test.

\subsection{Activity of Antioxidant Enzymes}

The activities of the antioxidant enzymes, i.e., superoxide dismutase (SOD), peroxidase (POD), and catalase (CAT) in the leaves of soybean plants grown under different watering intervals $(11,15$, and 19 days), in regard to PGPMs and/or ( $\mathrm{Si}+\mathrm{ZnPNs})$ applications are presented in Figure 5. In comparison to well water treatment $\left(\mathrm{IW}_{0}\right)$, the association between longer intervals $\left(\mathrm{IW}_{1}\right.$ and $\mathrm{IW}_{2}$ ) and soil salinity resulted in higher POD, SOD, and CAT. The most increased enzyme activity of SOD $(147.3 \%$ and $141.5 \%)$ and CAT $(353.3 \%$ and $140.0 \%)$ were observed under the $\mathrm{IW}_{1}$ condition, followed by the $\mathrm{IW}_{2}$ condition, comparing to the control of $\mathrm{IW}_{0}$ treatment. The individual application of Si-ZnNPs was superior to PGPMs in the activity of all tested antioxidant enzymes. The largest increases in the activity of CAT, POD, and SOD were observed as a result of foliar spraying with the nanocomposite $(\mathrm{Si}+\mathrm{Zn})$ in combination with soil application of PGPMs, which was more successful than their sole applications under the longest intervals $\left(\mathrm{IW}_{1}\right.$ and $\left.\mathrm{IW}_{2}\right)$ conditions. SOD activity under the effect of combined application increased by $101.2 \%, 66.4 \%$, and $31.5 \%$ under IW0, IW $\mathrm{IW}_{1}$, and $\mathrm{IW}_{2}$ over the controls of each treatment. Whereas the increased percentages in SOD under $\mathrm{IW}_{1}$ and $\mathrm{IW}_{2}$ in relevant to control of $\mathrm{IW}_{0}$ were much higher, $311.6 \%$ and $217.6 \%$. The same trend was observed for CAT activity. Although SOD and CAT activity increased under the $\mathrm{IW}_{1}$ and $\mathrm{IW}_{2}$ conditions, their levels retreat under the $\mathrm{IW}_{2}$ condition. The gradual increases in enzyme activity under prolonged conditions were for the POD enzyme (Figure 5). 


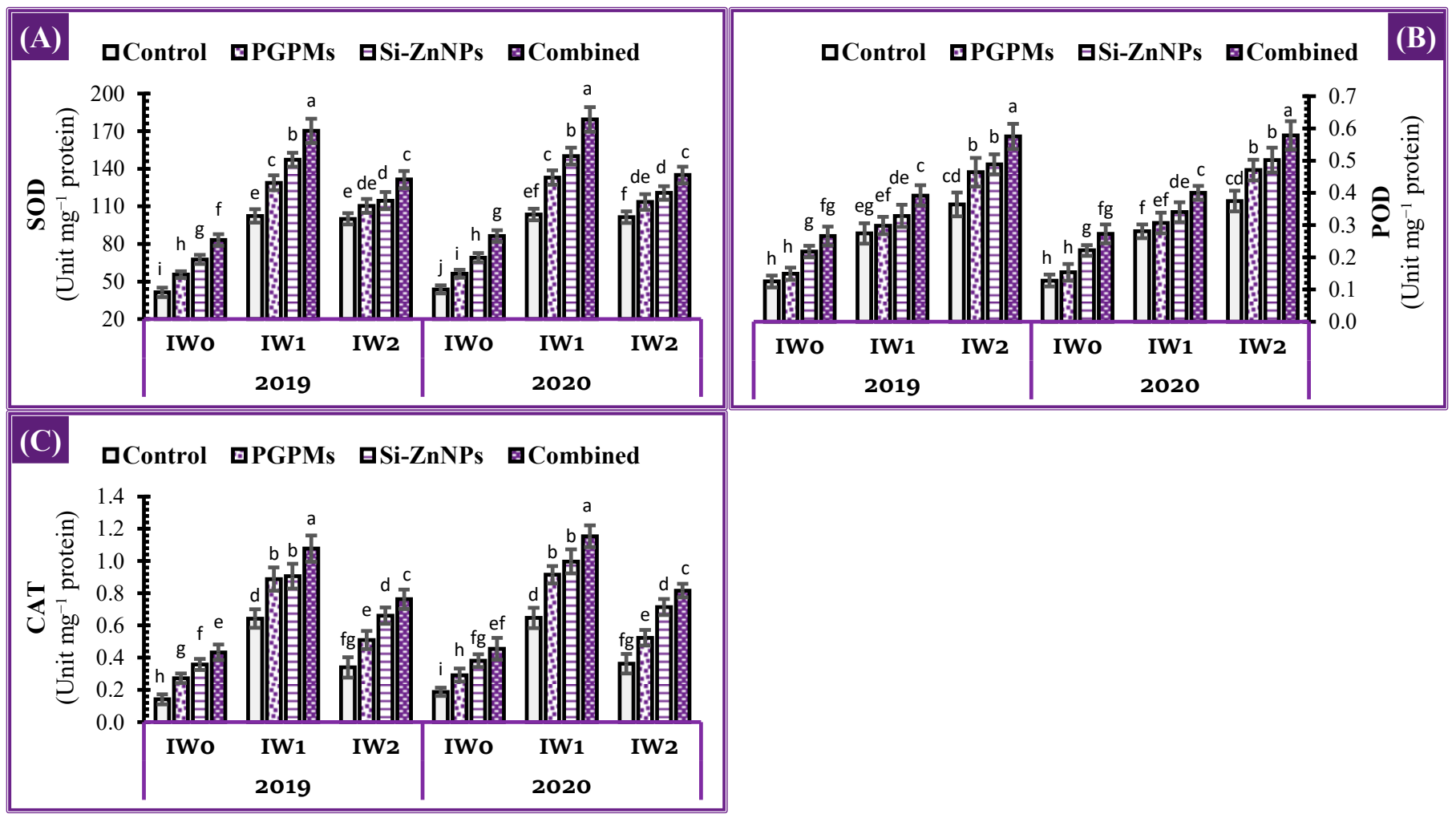

Figure 5. Influence of application of PGPMs, Si-ZnNPs and their combination on the activity of antioxidant enzymes, i.e., (A) SOD, (B) POD, and (C) CAT in the leaves of soybean plant grown in salt-affected soil with different levels of watering intervals $\left(\mathbf{I W}_{\mathbf{0}} ; 11\right.$ days, $\mathbf{I W}_{\mathbf{1}} ; 15$ days, and $\mathbf{I W}_{\mathbf{2}} ; 19$ days) during the successive 2019 and 2020 growing seasons. The data presented as means \pm SD. Means labeled with the same lower-case letter are not significantly different according to Duncan's Multiple Range Test.

\subsection{Oxidative Damage Status}

\subsubsection{Lipid Peroxidation}

Malondialdehyde (MDA) concentration under different watering intervals $\left(\mathrm{IW}_{0}, \mathrm{IW}_{1}\right.$, and $\left(\mathrm{IW}_{2}\right)$, as an indicator for the lipid peroxidation in leaves tissue of soybean plants, is shown in Figure 6. Exposing the control plants to the prolonged durations $\left(\mathrm{IW}_{1}\right.$ and $\left.\mathrm{IW}_{2}\right)$ increased the levels of MDA by about 2-fold and 3-fold higher than its level under $\mathrm{IW}_{0}$. Foliar spray with nanocomposite $(\mathrm{Si}+\mathrm{Zn})$ decreased the MDA levels under all intervals more than PGPMs did. The superior application in reducing the MDA levels was the co-application with PGPMs and Si-ZnNPs. Compared to each irrigation treatment control, the combined application could reduce the MDA level by $54.3 \%, 55.9 \%$, and $41.1 \%$ under $\mathrm{IW}_{0}, \mathrm{IW}_{1}$, and $\mathrm{IW}_{2}$, respectively. The potency of combined application to control the MDA levels under prolonged intervals was much higher under $\mathrm{IW}_{1}$, which reduced MDA levels by $14.8 \%$ than control of $\mathrm{IW}_{0}$. In contrast, under $\mathrm{IW}_{2}$, the combined application could not lessen the MDA level below or equal its level under $\mathrm{IW}_{0}$, whereas, on the contrary, it recorded an increase of $63.4 \%$ over $\mathrm{IW}_{0}$ control treatment (Figure $6 \mathrm{~A}$ ). 


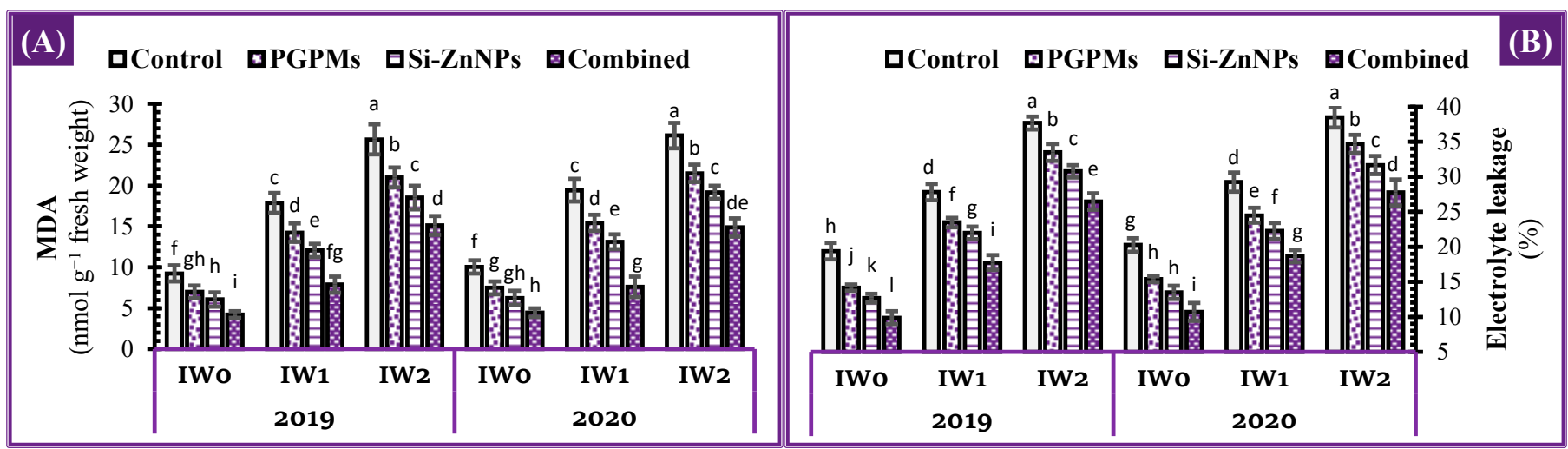

Figure 6. Influence of application of PGPMs, Si-ZnNPs and their combination on oxidative damage indicators, i.e., (A) malondialdehyde (MDA), and (B) electrolyte leakage (EL\%) in the leaves of soybean plant grown in salt-affected soil with different levels of watering intervals $\left(\mathbf{I W}_{\mathbf{0}} ; 11\right.$ days, $\mathbf{I W}_{\mathbf{1}} ; 15$ days, and $\mathbf{I W}_{\mathbf{2}} ; 19$ days) during the successive 2019 and 2020 growing seasons. The data presented as means \pm SD. Means labeled with the same lower-case letter are not significantly different according to Duncan's Multiple Range Test.

\subsubsection{Electrolytes Leakage Percentage}

In the 2019 and 2020 seasons, soybean plants that were irrigated at longer intervals $\left(\mathrm{IW}_{1}\right.$ and $\left.\mathrm{IW}_{2}\right)$ and grown in salt-affected soil had a higher electrolyte leakage percentage $(E L \%)$ than plants that have will irrigation ( $\mathrm{IW}_{0}$ ) (Figure $6 \mathrm{~B}$ ). The levels of EL\% in the control plants increased by around 1.5-fold and 2-fold when exposed to the extended durations $\left(\mathrm{IW}_{1}\right.$ and $\mathrm{IW}_{2}$ ) comparing to $\mathrm{IW}_{0}$ control treatment. Levels of EL\% were lower in all intervals when foliar spray with nanocomposite $(\mathrm{Si}+\mathrm{Zn})$ was used instead of PGPMs, where both applications (PGPMs or Si-ZnNPs) recorded a significant reduction than their controls. Co-application with PGPMs and Si-ZnNPs was found to be the most effective in lowering EL\% levels under all watering intervals levels. The combined application reduced EL\% levels by $49.1 \%, 36.2 \%$, and $29.7 \%$ under $\mathrm{IW}_{0}, \mathrm{IW}_{1}$, and $\mathrm{IW}_{2}$, respectively, as compared to the control of each watering treatment. The efficacy of co-application (PGPMs and nanocomposite $(\mathrm{Si}+\mathrm{Zn}))$ to regulate EL\% level over longer interval was much higher under $\mathrm{IW}_{1}$, which decreased EL\% by $8.4 \%$ compared to the control of $\mathrm{IW}_{0}$. The combined application under $\mathrm{IW}_{2}$ was unable to reduce EL\% below its observed under $\mathrm{IW}_{0}$, resulting in a $36.6 \%$ increase over the $\mathrm{IW}_{0}$ control (Figure $6 \mathrm{~B}$ ).

\subsection{Plant Water Relations}

Soybean plants that were irrigated at longer intervals $\left(\mathrm{IW}_{1}\right.$ and $\mathrm{IW}_{2}$ ) and grown in salt-affected soil had lower water relations characteristic in the plant (stomatal conductance (gs) and relative water content (RWC)) than plants that were well irrigated $\left(\mathrm{IW}_{0}\right)$ (Figure 7). Under the mentioned conditions, for the controls of $\mathrm{IW}_{1}$ and $\mathrm{IW}_{2}$, RWC recorded a decrease by $12.3 \%$ and $23.6 \%$, while gs recorded $17.4 \%$ and $29.9 \%$ decrease below control of $\mathrm{IW}_{0}$. 


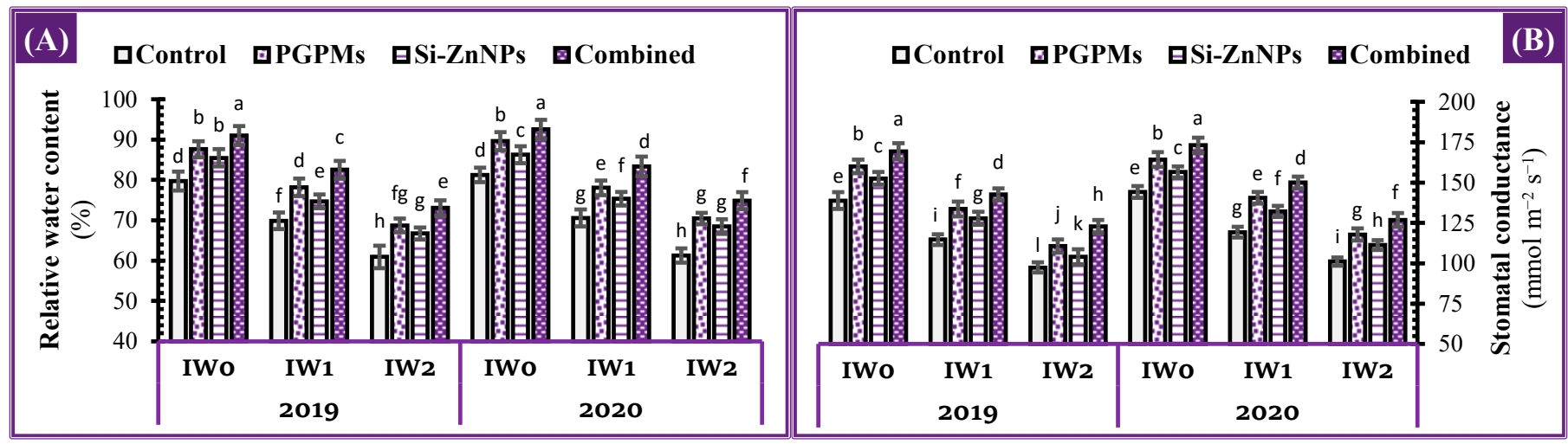

Figure 7. Influence of application of PGPMs, Si-ZnNPs and their combination on water relations, i.e., (A) leaf relative water content, and (B) stomatal conductance in the leaves of soybean plant grown in salt-affected soil with different levels of watering intervals $\left(\mathbf{I W}_{\mathbf{0}} ; 11\right.$ days, $\mathbf{I W}_{\mathbf{1}} ; 15$ days, and $\mathbf{I W}_{\mathbf{2}} ; 19$ days) during the successive 2019 and 2020 growing seasons. The data presented as means \pm SD. Means labeled with the same lower-case letter are not significantly different according to Duncan's Multiple Range Test.

Under $\mathrm{IW}_{0}, \mathrm{IW}_{1}$, and $\mathrm{IW}_{2}$ condition, RWC began to steadily improve over their controls as a result of individual application of PGPMs by $9.9 \%, 11.8 \%$, and $12.8 \%$, whereas nanocomposite $(\mathrm{Si}+\mathrm{Zn}$ ) had lower effects which increased by $7.3 \%, 6.9 \%$, and $9.5 \%$, respectively. The highest RWCs under all watering intervals $\left(\mathrm{IW}_{0}, \mathrm{IW}_{1}\right.$, and $\left.\mathrm{IW}_{2}\right)$ were observed for the combined application PGPMs and Si-ZnNPs, which increased by $14.2 \%, 18.1 \%$, and $19.9 \%$, respectively. Although the highest percentage over its own control was recorded for combined application under the most extended watering interval $(19 \mathrm{~d})$, its positive effect over the threshold (control of $\mathrm{IW}_{0}$ ) was limited to $\mathrm{IW}_{1}(15 \mathrm{~d}$ ) which increased by $3.6 \%$, while under $\mathrm{IW}_{2}$ decreased the RWC by $8.3 \%$.

The same trend was observed for stomatal conductance (Figure 7). The co-application (PGPMs and Si-ZnNPs) under $\mathrm{IW}_{0}, \mathrm{IW}_{1}$, and $\mathrm{IW}_{2}$ comparing with their own controls increased the stomatal conductance by $22.0 \%, 24.4 \%$, and $26.2 \% \%$, respectively, whereas when comparing with control of $\mathrm{IW}_{0}$ recorded an increase under $\mathrm{IW}_{1}$ by $2.7 \%$, and a decrease under $\mathrm{IW}_{2}$ by $11.5 \%$ (Figure $7 \mathrm{~B}$ ).

\subsection{Yield Related Traits and Seed Quality}

The soybean yield-related traits such as the number of pods plant ${ }^{-1}, 100$-seed weight, and seed yield ( $\mathrm{t} \mathrm{ha} \mathrm{a}^{-1}$ ), as well as the seed nutritional quality such as the content of protein and carbohydrate, were negatively affected and significantly declined in soybean plants grown in salt-affected soil and subjected to the longer irrigation intervals ( $\mathrm{IW}_{1}$ and $\mathrm{IW}_{2}$ ) compared to plants under IW $_{0}$ condition during the successive 2019 and 2020 growing seasons (Table 1).

The yield-related traits were positively improved under individual applications of PGPMs or Si-ZnNPs, as well as their combination under all tested irrigation intervals $\left(\mathrm{IW}_{0}, \mathrm{IW}_{1}\right.$, and $\left.\mathrm{IW}_{2}\right)$. Seed yield under well irrigation $\left(\mathrm{IW}_{0}\right)$ was related to the type of application, where the sole application increased the seed yield by $19.1 \%$ for PGPMs and $24.8 \%$ for Si-ZnNPs. Additionally, as expected, the combined application (PGPMs and $\mathrm{Si}-\mathrm{ZnNPs}$ ) recorded the highest seed yield (35.3\%) over the $\mathrm{IW}_{0}$ control. Meanwhile, under the extended watering intervals $\left(\mathrm{IW}_{1}\right.$ and $\left.\mathrm{IW}_{2}\right)$, the seed yield of control decreased dramatically by $22.2 \%$ and $44.6 \%$ below the control of $\mathrm{IW}_{0}$. Application of nanocomposite $(\mathrm{Si}+\mathrm{Zn})$ was more effective than PGPMs in increasing the yield traits, which increased the seed yield by $24.8 \%, 23.8 \%$, and $32.7 \%$, compared to the controls of $\mathrm{IW}_{0}, \mathrm{IW}_{1}$, and $\mathrm{IW}_{2}$. The combined application under the same watering intervals recorded the highest seed yield, which increased by $35.3 \%, 39.7 \%$, and $50.1 \%$, over the controls of $\mathrm{IW}_{0}, \mathrm{IW}_{1}$, and $\mathrm{IW}_{2}$. On the other hand, the effect of combined application (PGPMs and Si-ZnNPs), when compared to the control of $\mathrm{IW}_{0}$, revealed that the only positive increase was under $\operatorname{IW}_{1}(8.6 \%)$, while 
under $\mathrm{IW}_{2}$, the seed yield decreased by $16.8 \%$ below the control of IW ${ }_{0}$. The same trends were observed for pods number per plant and 100 seeds weight.

Table 1. Characteristics of yield and seed nutritional quality of soybean plant treated with PGPMs and/or Si-ZnNPs, and grown in salt-affected soil with different levels of watering intervals $\left(\mathbf{I W}_{\mathbf{0}} ; \mathbf{1 1}\right.$ days, $\mathbf{I W}_{\mathbf{1}} ; \mathbf{1 5}$ days, and $\mathbf{I W}_{\mathbf{2}} ; 19$ days) during 2019 and 2020 growing seasons.

\begin{tabular}{|c|c|c|c|c|c|c|c|}
\hline Season & Irrigation & Treatments & $\begin{array}{l}\text { Pods Plant }^{-1} \\
\text { (No.) }\end{array}$ & $\begin{array}{l}\text { 100-Seed } \\
\text { (g) }\end{array}$ & $\begin{array}{l}\text { Seed Yield } \\
\left(\mathrm{t} \mathrm{ha} \mathbf{a}^{-1}\right)\end{array}$ & $\begin{array}{c}\text { Protein Seed }^{-1} \\
(\%)\end{array}$ & $\begin{array}{c}\text { Carb. Seed } \\
(\%)\end{array}$ \\
\hline \multirow{12}{*}{2019} & \multirow{4}{*}{$\mathrm{IW}_{0}$} & Control & $82.4 \pm 5.2 \mathrm{de}$ & $16.1 \pm 0.8 c$ & $1.7 \pm 0.08 \mathrm{e}$ & $28.1 \pm 1.0 \mathrm{~cd}$ & $20.2 \pm 1.2 c$ \\
\hline & & PGPMs & $99.7 \pm 4.7 \mathrm{c}$ & $17.5 \pm 1.1 \mathrm{~b}$ & $2.0 \pm 0.14 c$ & $33.1 \pm 1.1 \mathrm{~b}$ & $23.4 \pm 1.2 \mathrm{~b}$ \\
\hline & & Si-ZnNPs & $105.6 \pm 4.0 \mathrm{~b}$ & $18.0 \pm 1.0 \mathrm{~b}$ & $2.1 \pm 0.11 b$ & $35.1 \pm 1.4 \mathrm{~b}$ & $26.0 \pm 1.0 \mathrm{a}$ \\
\hline & & PGPMs + Si-ZnNPs & $115.3 \pm 4.1 \mathrm{a}$ & $19.4 \pm 1.3 \mathrm{a}$ & $2.3 \pm 0.12 \mathrm{a}$ & $38.3 \pm 1.6 \mathrm{a}$ & $27.9 \pm 1.0 \mathrm{a}$ \\
\hline & \multirow{4}{*}{$\mathrm{IW}_{1}$} & Control & $64.6 \pm 3.8 \mathrm{~h}$ & $13.7 \pm 0.8 \mathrm{eg}$ & $1.3 \pm 0.07 \mathrm{~h}$ & $18.4 \pm 1.4 \mathrm{~g}$ & $15.9 \pm 0.9$ ef \\
\hline & & PGPMs & $79.6 \pm 3.2 \mathrm{e}$ & $14.5 \pm 0.5 \mathrm{de}$ & $1.5 \pm 0.09 \mathrm{f}$ & $23.8 \pm 1.2 \mathrm{e}$ & $18.7 \pm 0.8 \mathrm{~cd}$ \\
\hline & & Si-ZnNPs & $86.4 \pm 3.0 \mathrm{~d}$ & $15.2 \pm 1.0 \mathrm{~cd}$ & $1.6 \pm 0.11 \mathrm{e}$ & $26.3 \pm 1.3 \mathrm{~d}$ & $19.9 \pm 1.1 c$ \\
\hline & & PGPMs + Si-ZnNPs & $96.1 \pm 4.6 \mathrm{c}$ & $16.3 \pm 1.3 \mathrm{c}$ & $1.8 \pm 0.09 \mathrm{~d}$ & $30.1 \pm 1.5 \mathrm{c}$ & $22.2 \pm 1.1 \mathrm{~b}$ \\
\hline & \multirow{4}{*}{$\mathrm{IW}_{2}$} & Control & $57.7 \pm 2.5 \mathrm{i}$ & $11.9 \pm 0.7 \mathrm{~h}$ & $0.9 \pm 0.07 \mathrm{k}$ & $11.3 \pm 1.1 \mathrm{i}$ & $11.4 \pm 1.0 \mathrm{~h}$ \\
\hline & & PGPMs & $70.4 \pm 4.3 \mathrm{~g}$ & $12.5 \pm 0.9 \mathrm{gh}$ & $1.1 \pm 0.07 \mathrm{j}$ & $14.4 \pm 1.3 \mathrm{~h}$ & $13.1 \pm 0.9 \mathrm{gh}$ \\
\hline & & Si-ZnNPs & $73.2 \pm 3.3 \mathrm{fg}$ & $13.2 \pm 1.1 \mathrm{fg}$ & $1.2 \pm 0.06 \mathrm{i}$ & $16.7 \pm 0.9 \mathrm{gh}$ & $14.4 \pm 0.6 \mathrm{fg}$ \\
\hline & & PGPMs + Si-ZnNPs & $76.9 \pm 4.4 \mathrm{ef}$ & $13.8 \pm 1.1 \mathrm{ef}$ & $1.4 \pm 0.08 \mathrm{~g}$ & $20.9 \pm 1.91 \mathrm{f}$ & $17.2 \pm 1.5 \mathrm{de}$ \\
\hline \multirow{12}{*}{2020} & \multirow{4}{*}{$\mathrm{IW}_{0}$} & Control & $84.0 \pm 4.1 \mathrm{e}$ & $16.3 \pm 0.9 \mathrm{~cd}$ & $1.8 \pm 0.09 \mathrm{~d}$ & $29.5 \pm 0.9 \mathrm{de}$ & $21.3 \pm 1.9 \mathrm{~cd}$ \\
\hline & & PGPMs & $102.3 \pm 2.4 c$ & $17.3 \pm 0.9 \mathrm{bc}$ & $2.1 \pm 0.07 c$ & $33.9 \pm 1.9 c$ & $24.7 \pm 1.1 \mathrm{~b}$ \\
\hline & & Si-ZnNPs & $107.8 \pm 3.5 b$ & $18.2 \pm 1.1 \mathrm{~b}$ & $2.2 \pm 0.05 b$ & $36.5 \pm 1.1 \mathrm{~b}$ & $27.2 \pm 0.9 \mathrm{a}$ \\
\hline & & PGPMs + Si-ZnNPs & $118.3 \pm 3.9 \mathrm{a}$ & $20.5 \pm 0.9 \mathrm{a}$ & $2.5 \pm 0.11 \mathrm{a}$ & $39.7 \pm 1.2 \mathrm{a}$ & $28.8 \pm 1.3 \mathrm{a}$ \\
\hline & \multirow{4}{*}{$\mathrm{IW}_{1}$} & Control & $68.9 \pm 2.7 \mathrm{f}$ & $14.9 \pm 0.9$ ef & $1.3 \pm 0.09 \mathrm{f}$ & $19.6 \pm 1.4 \mathrm{~h}$ & $16.8 \pm 1.1 \mathrm{fg}$ \\
\hline & & PGPMs & $83.3 \pm 2.3 \mathrm{e}$ & $15.5 \pm 0.9 \mathrm{df}$ & $1.6 \pm 0.09 \mathrm{e}$ & $25.2 \pm 1.4 \mathrm{f}$ & $19.4 \pm 1.2 \mathrm{de}$ \\
\hline & & Si-ZnNPs & $90.4 \pm 3.3 \mathrm{~d}$ & $16.1 \pm 0.9$ ce & $1.8 \pm 0.08 \mathrm{~d}$ & $27.7 \pm 1.2 \mathrm{e}$ & $20.6 \pm 1.0 \mathrm{~cd}$ \\
\hline & & PGPMs + Si-ZnNPs & $102.2 \pm 4.6 \mathrm{c}$ & $16.9 \pm 0.8 c$ & $2.0 \pm 0.11 c$ & $31.1 \pm 1.7 \mathrm{~d}$ & $22.6 \pm 1.1 c$ \\
\hline & \multirow{4}{*}{$\mathrm{IW}_{2}$} & Control & $60.5 \pm 4.5 \mathrm{~g}$ & $13.1 \pm 1.1 \mathrm{~g}$ & $1.0 \pm 0.08 \mathrm{~g}$ & $12.5 \pm 0.9 \mathrm{j}$ & $12.5 \pm 1.1 \mathrm{i}$ \\
\hline & & PGPMs & $71.0 \pm 3.1 \mathrm{f}$ & $14.3 \pm 1.0 \mathrm{fg}$ & $1.3 \pm 0.08 \mathrm{f}$ & $15.6 \pm 1.1 \mathrm{i}$ & $14.3 \pm 0.7 \mathrm{hi}$ \\
\hline & & Si-ZnNPs & $73.5 \pm 3.7 \mathrm{f}$ & $14.6 \pm 1.0 \mathrm{f}$ & $1.3 \pm 0.07 \mathrm{f}$ & $18.4 \pm 1.2 \mathrm{~h}$ & $15.7 \pm 0.9 \mathrm{gh}$ \\
\hline & & PGPMs + Si-ZnNPs & $83.3 \pm 5.4 \mathrm{e}$ & $15.4 \pm 1.0 \mathrm{df}$ & $1.6 \pm 0.06 \mathrm{e}$ & $22.2 \pm 2.1 \mathrm{~g}$ & $18.4 \pm 1.6 \mathrm{ef}$ \\
\hline \multirow{3}{*}{$F$ test } & \multirow{3}{*}{\multicolumn{2}{|c|}{$\begin{array}{l}\text { Deficit irrigation } \\
\text { Soil and foliar treatments } \\
\text { Irrigation } X \text { Treatments }\end{array}$}} & $* * *$ & $* *$ & $* * *$ & $* * *$ & $* * *$ \\
\hline & & & $* * *$ & $* * *$ & $* * *$ & $* * *$ & $* * *$ \\
\hline & & & $*$ & ns & $* *$ & ns & ns \\
\hline
\end{tabular}

Means followed by different lower-case letters indicate significant differences among treatments according to Duncan's Multiple Range Test $(P<0.05)$. Values are presented as means \pm standard deviation $(\mathrm{SD}) .{ }^{* * *, * * * *}$, and ns denote significance at $P<0.001, P<0.01$, and non-significant, respectively. PGPMs: Plant growth-promoting microbes, NP: Nano particles, Carb: Carbohydrate content, IW: Interval watering.

Seed content from proteins and carbohydrates was strongly related to 100 seed weight. The combined application increased the protein content by $36.2 \%, 63.5 \%$, and $84.1 \%$, and carbohydrates content by $38.1 \%, 40.1 \%$, and $51.9 \%$, compared to the controls of $\mathrm{IW}_{0}, \mathrm{IW}_{1}$, and $\mathrm{IW}_{2}$. The pronouncing of these greatest increase was revealed after comparing with the control of $\mathrm{IW}_{0}$, where the positive increases were only under $\mathrm{IW}_{1}$, which are $7.0 \%$ for proteins, and $9.9 \%$ for carbohydrates (Table 1 ).

\section{Discussion}

Deficit irrigation, drought, and soil salinity have the most important detrimental effects on the growth, productivity, and sustainability of crops, by affecting both plant and soil health. Osmotic stress (salinity or drought) negatively affects the root architecture and the ecosystem in cultivated soil, which reflects on soil chemical and physical traits, and indirectly connects with the mineral nutrition, water relations, antioxidant defense system, and metabolism of soybean, which reflect in turn on plant development, yield, and related traits. Nevertheless, little is known about the plant's adaptive mechanisms. The current study has been investigated to evaluate the response of individual soil application of plant 
growth-promoting microbes or foliar spray of Si-Zn nanocomposite, and their mixture on mitigation the harmful effects of water deficit and soil salinity as well as improving the growth and development of cultivated soybean plants within deficit irrigation.

\subsection{Yield Physiology under Well Irrigation}

\subsubsection{Rhizosphere-Shoot Connections}

Cultivation of the crops in salt-affected soil exhibits various negative impacts on plant aspects related to crop growth, which depend on soil salinity level, tolerance degree of the cultivated plant, and the availability of water in the soil. Under well-watering conditions, the deleterious effects of soil salinity on cultivated plants will be lessened to minimum levels. Plants can suffer from a variety of nutritional issues as a result of soil salinity. The abundance of a particular ion in soil solution, such as $\mathrm{Na}^{+} \mathrm{or} \mathrm{Cl}^{-}$, is thought to be the key cause of these nutrition problems. The presence of these soluble ions will reduce the availability of other essential minerals in the soil, resulting in decreased element accessibility and uptake by plants. Hence, treating soybean plants grown in salt-affected soil with PGPMs and/or Si-ZnNPs could boost the tolerance level to soil salinity, reflecting on maximizing the vegetative soybean growth (Figure 1).

Application of PGPMs (B. japonicum and T. harzianum) promoes the health of rhizosphere and plant, which minimizes the percentage of exchangeable $\mathrm{Na}$ (ESP) in the soil (Figure 1A), increase the solubility of essential minerals in the soil, and subsequently, increases their concentration in the shoot tissues, especially for $\mathrm{K}^{+}$ions (Figure 2B). Enhancing the solubility, uptake and translocation of mineral nutrients in soybean by PGPMs application improved vegetative growth (Figure 1).

The $B$. japonicum (USDA 110) strain is capable of producing higher amounts of the growth-promoting phytohormones (IAA, $\mathrm{GA}_{3}$, and zeatin) in the growth medium [45]. Therefore, inoculation of soybean seeds with $B$. japonicum not only promotes plant growth by symbiotic $\mathrm{N}_{2}$ fixation but also has additional growth-promoting properties. The presence of IAA was linked to the stimulation of physiological and biochemical processes related to nodule formation and root development [45]. IAA raised the number of lateral roots and root hairs, increasing the plant-microbes interaction, which significantly affected nodule development and increased the nodules number [32]. Additionally, zeatin may have a role at the beginning of nodulation, while synthesized $\mathrm{GA}_{3}$ could be effective in promoting soybean shoot growth [45]. The genus Trichoderma is widely used as a biological control agent by inhibiting plant pathogens and promoting plant growth by producing different types of secondary metabolites [36]. Even under non-stressed condition, the application of $T$. harzianum could colonize with soybean roots, causing some anatomical changes such as increasing the thickness of the root (cortex, epidermis, and vascular cylinder) and also increasing the thickness of the mesophyll layer [46]. Therefore, inoculation of soybean seeds with the microbial consortium (B. japonicum and T. harzianum) magnified the growth-promoting effects, which subsequently reflecting in significant increases in root length, nodules, and total leaves area (Figure 1). The successful colonization with PGPMs increases the root exudates that directly affect soil biota activity and the efficiency of soil microbes in transforming the complex organic substrates and releasing the soil minerals, facilitating plant growth.

Foliar application of Si-Zn nanoparticles reduced the ESP in the soil and increased the nodules mass, root length, and total leaves area plant ${ }^{-1}$ (Figure 1). These positive effects could be related to the role of $\mathrm{Zn}$ in synthesizing some phytohormones like auxins. Zinc has an essential role in the biosynthesis of IAA from tryptophan [37], which responsible for nitrogen fixation, regulating the nodule formation, number and size of nodules [47]. Additionally, the application of $\mathrm{Zn}$ increased the content of endogenous $\mathrm{GA}_{3}$ [37], which alongside IAA, play an active role in cell enlargement, leading to elongating both of root and shoot system [47]. Moreover, Si has many well-documented beneficial effects on plant health. Si application to leguminous crops had the ability to increase the capacity of plant roots to release more isoflavonoids, which entice $\mathrm{N}_{2}$-fixing rhizobacteria [48], which is 
reflected by a greatly increase in the nodule size and number (Figure 1B). Additionally, soybeans treated with Si had a larger root diameter [48].

The combined soil and foliar application of PGPMs and Si-ZnNPs, respectively, boosted the performance of the soybean plant to its maximum capacity, which reduced the ESP in the soil to $32.5 \%$ lower than control, while nodule DW increased by $19.1 \%$, root length by $28.6 \%$, and leaves area plant ${ }^{-1}$ by $36.3 \%$ over control (Figure 1 ). These positive findings are in agreement with our previous work on faba bean [25], where the dual application of PGPR and silica recorded heavier nodule dry weight and root length.

\subsubsection{Physio-Biochemical Changes and Yield Relationship}

The healthy vegetative growth of plants is a significant sign for the physiological functions, and their related assimilates follow the plant's genetic codes written for optimum condition, so the application of any growth-promoting material will transfer the physiological processes to a new level and enhance the metabolism, which is reflected in a promotion of all growth stages and the better development of the plants. From this point of view, all the tested applications PGPMs and/or Si-ZnNPs increased all the studied physiological parameters, where the ultimate increases were for the foliar and soil combined application (PGPMs and Si-ZnNPs).

Under well irrigation conditions, the combined application significantly increased the photosynthetic pigments (Figure 3), total soluble sugars (TSS), total soluble proteins (TSP) while decreasing the osmolytes (free amino acids and proline) (Figure 4), while increasing the activity of antioxidant enzymes (Figure 5), which is definite reflected in a decrease of the oxidative damage in the form of lipid peroxidation and EL\% to its minimum levels (Figure 6). The previous motivation in enzymatic and non-enzymatic antioxidants positively affects the photosynthetic machinery, increasing the assimilation rate and assimilates, which were related to the increases in stomatal conductance and RWC (Figure 7).

The previously mentioned positive effects may result from the integration between every growth promoter used and the multi-functions of other tested promoters. Plant growth-promoting microbes (PGPMs) may establish themselves on the plant roots, stay there and compete with other microbes while promoting plant growth. Under normal conditions, Trichoderma can cause anatomical changes in different soybean organs and increases the stomatal index of the soybean plants [46]. Regarding mineral nutrition with nanoparticles $(\mathrm{Si}+\mathrm{Zn})$, zinc plays a variety of roles in plant development, pollen grain formation, and productivity, among other micronutrients. In legume crops, Zn requirements are higher during the reproductive stage than during the vegetative stage. If the amount of $\mathrm{Zn}$ available is insufficient, the photosynthesis process will be hampered by the altered structure of chloroplasts, resulting in reduced stem growth, smaller leaves, and later maturity [37]. $\mathrm{Zn}$ is involved in a variety of metabolic and enzymatic processes, as well as the production of growth hormones, which are essential for chlorophyll formation [39]. Since pollen grains contain a higher amount of $Z n$, the higher number of pods plant ${ }^{-1}$ and 100-seed weight may be due to the role of $\mathrm{Zn}$ in the reproductive process during fertilization [47]. The role of $\mathrm{Zn}$ in photosynthesis, $\mathrm{N}_{2}$ metabolism, IAA synthesis, and several other enzymatic reactions, where $\mathrm{Zn}$ acts as a cofactor [39], and thus influences plant growth and development, which could explain the increase in the number of seeds per pod and 100-seed weight. Additionally, Zn improved carbohydrate and protein synthesis as well as their transport to the developed seed, resulting in a larger source size [47]. Soybean plants treated with silicon displayed improvements in net photosynthesis, stomatal conductance (gs), and the content of intercellular $\mathrm{CO}_{2}$, even when plants were exposed to high salinity stress. This is because absorbed Si builds up in the leaves and stems' cell walls, enabling the plant to start standing up more and increases the size usable for solar radiation and gas exchange, thereby increasing the performance of Photosystem II. Furthermore, $\mathrm{Si}$ accumulation enables stomata to open, which may increase transpiration rate and $\mathrm{CO}_{2}$ influx. 
From this perspective, $\mathrm{Si}$ treated leaves may be responsible for sustaining transpiration and enabling the crop to use the available water to achieve a higher net assimilation rate [48].

Increasing the seed yield and all its related traits under the combined application (Table 1) revealed that these increases are correlated to enhancements that occurred to all previously mentioned parameters. But, which variable(s) was(were) more related to the increases in yield parameters. The answer to this question is extracted from the parallel coordinates' comparison between all variables and their shares to other variables (Figure 8). The increases in yield-related traits were higher for the combined application (PGPMs and Si-ZnNPs) > Si-ZnNPs > PGPMs > control under $\mathrm{IW}_{0}$ conditions. Comparing all variables between combined application and Si-ZnNPs application reveal that the positive parallel increases were only for antioxidant enzymes (CAT, POD, and SOD) and osmolytes (FAA and proline) which protected the photosynthetic pigments (chlorophylls and carotenoids) and increased their efficiency, which directly and indirectly affected the physiological processes and increased the yield and its quality even under well-watering condition (Figure 8).

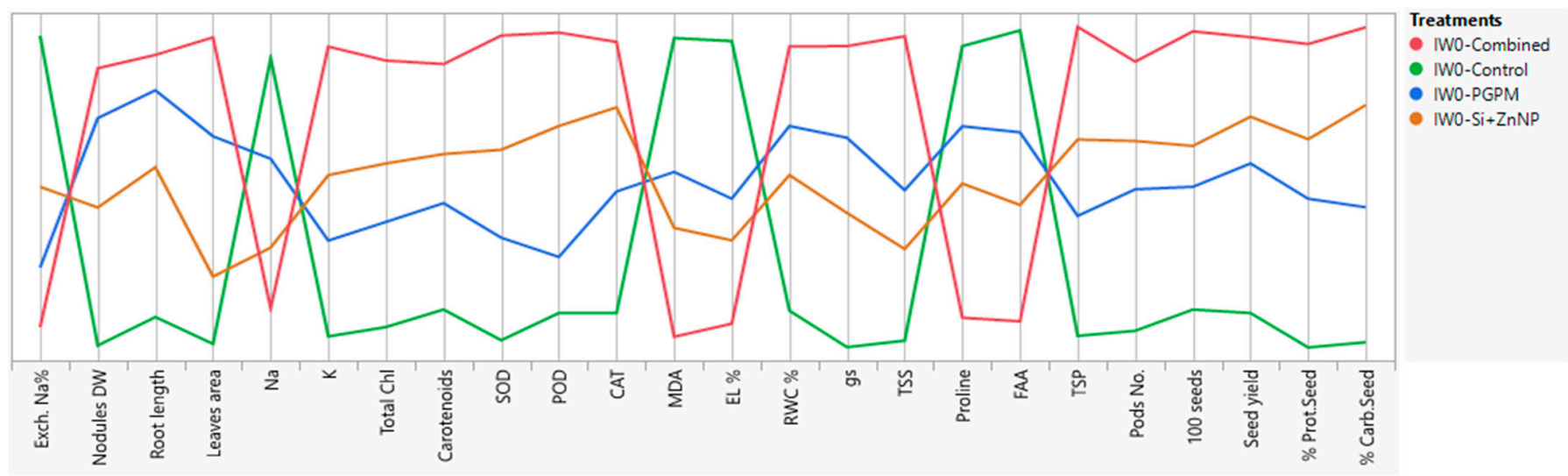

Figure 8. Parallel coordinates comparison plot showing how the studied variables of soybean grown under well irrigation changes in relation to the type of growth promoters (PGPMs and/or Si-ZnNPs).

\subsection{Yield Physiology under Deficit Irrigation}

Cultivation in salt-affected soil is a risky practice, which needs more attention to other environmental factors. The most critical factor in this type of soil is the availability of water used for irrigation. Any tiny delay in irrigation by more than recommended duration in this specific area will expose the grown plants to different degrees from a combination of dual stress (water deficit and salinity stresses). Both of those stresses will initiate many signal transduction chains depending on the defense genome in the cultivated plant, reflected on multi-crosstalk between cells of root and shoot, and finally translate to multiple biochemical and physiological changes related mainly to plant survival under this type of stresses [49]. If the cultivated plant doesn't have good defense genes, it will start suffering from the deleterious effects of these abiotic stresses, which is reflected in the plant growth, development, and productivity. Under this condition, exogenous support with growth promoters will add many benefits and extra defense mechanisms to the plants.

Subjected soybean plants to two levels of deficit irrigation $\left(\mathrm{IW}_{1}\right.$ and $\left.\mathrm{IW}_{2}\right)$ resulted in significant reductions in many of variables (nodules D, root length, total leaves area, $\mathrm{K}$, photosynthetic pigments, TSP, RWC, gs, and yield traits) and increases in other variables (ESP, Na, TSS, FAA, proline, SOD, POD, CAT, MDA, and EL\%), comparing to the relative levels under $\mathrm{IW}_{0}$ (Figure 9A). A closer look at the parallel comparison between these variables (Figure 9A) under $\mathrm{IW}_{2}$ comparing to the level of change in $\mathrm{IW}_{0}$ and $\mathrm{IW}_{1}$ reveal that the most effective direct negative variables that started the deleterious events are ESP in the soil and $\mathrm{Na}^{+}$content in the plant tissues which reflected on increasing the 
peroxidation levels and EL\%. Unfortunately, although the content of osmolytes (FAA and proline) and activity of POD were much higher, they can't mitigate enough the impact of water deficit, which resulted in the maximum recorded reduction in RWC and gs, leading to reduced carotenoids (antioxidant) content which is reflected by more inhibition and oxidation of chlorophylls and subsequently the assimilation rate and extremely inhibited the growth of root and shoot system.
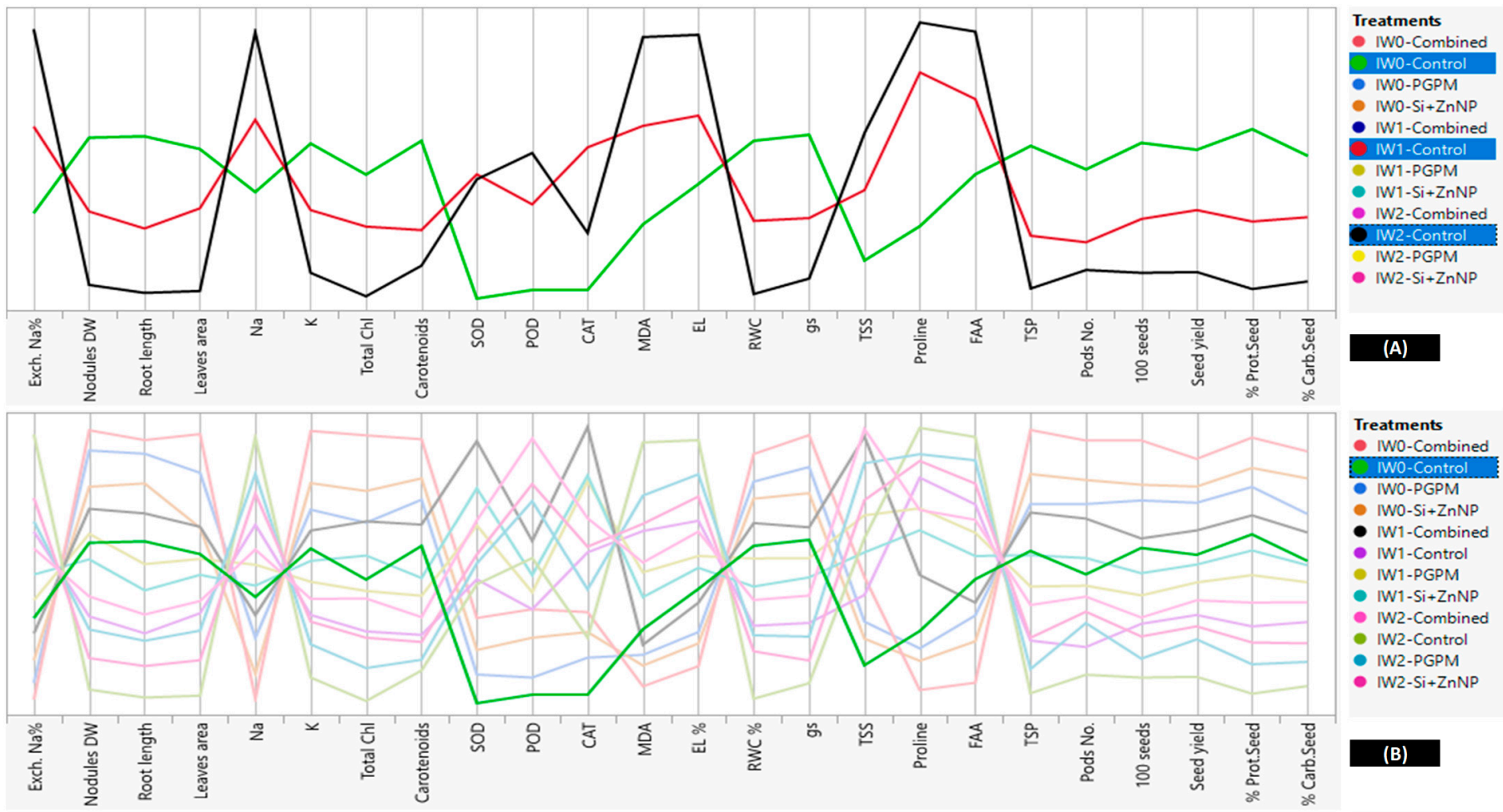

Treatments

Treatments
IWO-Combined IW0-Control IWO-PGPM - IWO-Si+ZnNP - IW1-Combined - IW1-Control - IW1-PGPM

- IW1-Si+ZnNP

IW2-Combined

- IW2-Control

- IW2-PGPM

- IW2-Si+ZnNP

\section{(B)}

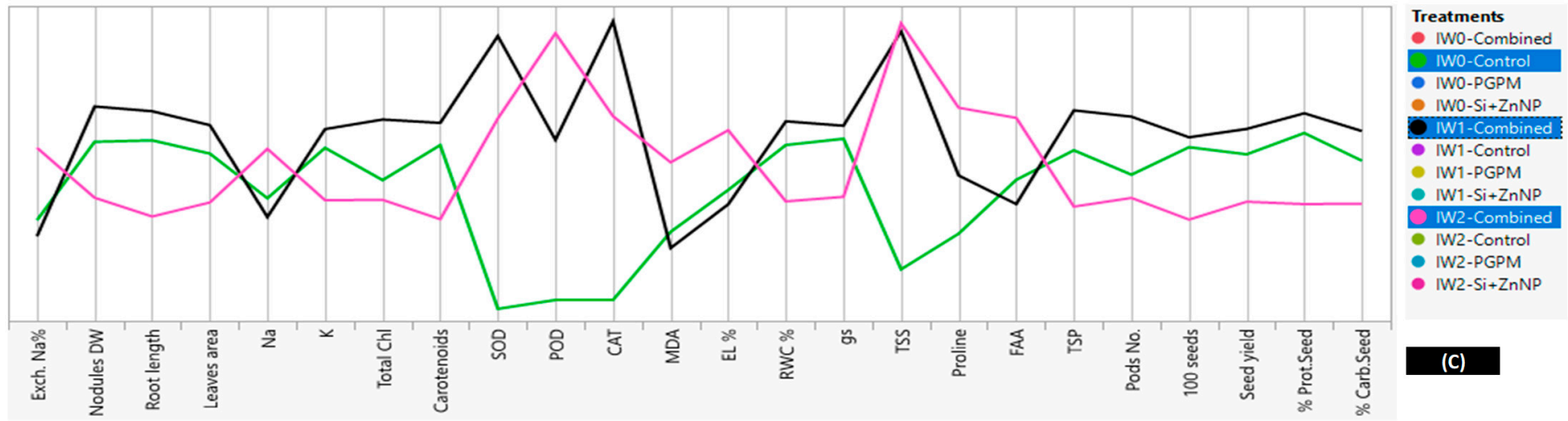

Figure 9. Parallel coordinates comparison plot showing how soybean studied variables changes in relation to the changes in irrigation levels, (A) comparison between controls under different intervals of watering, (B) comparison between all treatments in regard to the control of well watering as a reference, $(\mathbf{C})$ comparison between the effect dual application of PGPMs and Si-ZnNPs under the higher levels of deficit irrigation in regard to control of well watering as a reference.

Parallel comparison between the levels of variables in the control of $\mathrm{IW}_{0}$ (sharpen green line) in regard to all other applications (fade lines) under all watering treatments found that the position of most control parameters (sharpen green line, Figure 9B) laid on the middle between all other variables under $\mathrm{IW}_{0}, \mathrm{IW}_{1}$, and $\mathrm{IW}_{2}$ except for antioxidant enzymes (SOD, POD, and CAT) and TSS which recorded the lowest levels between all treatments (Figure 9B). This observation reveals that the most sensitive parameters related to defense mechanisms are the antioxidant enzymes and TSS. 
Regarding the best-recommended application for motivating the growth and yield of soybean plant grown under different watering intervals, which is the co-application of (PGPMs and Si-ZnNPs), the parallel comparison for this combined treatment under the longer watering intervals ( $\mathrm{IW}_{1}$ and $\mathrm{IW}_{2}$ ) is presented in Figure $9 \mathrm{C}$. For more clarity, the comparison was made concerning the control of $\mathrm{IW}_{0}$ to reveal why the combined application under the most extended duration $\left(\mathrm{IW}_{2}\right)$ was not enough to produce yield near enough from the control yield under $\mathrm{IW}_{0}$. Although motivated the TSS to its maximum limit under $\mathrm{IW}_{2}$ comparing to $\mathrm{IW}_{1}$, the antioxidant enzymes didn't take this trend where the activity levels of SOD and CAT start to retreat under $\mathrm{IW}_{2}$. This retreat is more correlated to the highest increase in EL\% and MDA, which indicated that cell membranes were suffering from severe oxidation, which has a direct correlation with decreasing the RWC, gs, and carotenoids, which in turn minimize the chlorophylls, plant growth and 100-seed weight (Figure 9C).

\section{Materials and Methods}

\subsection{Experimental Layout}

Two field trials were performed in 2019 and 2020 at Sakha Agricultural Research Station, Agricultural Research Center (ARC), Egypt, to assess the impacts of seed inoculation with a mixture of two microorganisms; (1) the bacteria Bradyrhizobium japonicum (USDA 110) and (2) the fungi Trichoderma harzianum, in addition to the foliar application of some beneficial and micro-elements in nanoparticles form on soil chemistry, plant vegetative growth, the activity of the antioxidant defense system, and related physiological attributes, yield and seed quality of soybean plants subjected to different irrigation intervals every 11 $\left(\mathrm{IW}_{0}\right), 15\left(\mathrm{IW}_{1}\right)$ and $19\left(\mathrm{IW}_{2}\right)$ days at salt-affected soil.

The experiment was laid out in a split-plot design with three replicates. The main plots were divided into irrigation intervals, and sub-plots were divided into the growth promoters' treatments (Control, PGPMs, Si-ZnNPs, and the combination of PGPMs and Si-ZnNPs). The area of the sub-plot was $42 \mathrm{~m}^{2}$, including 10 rows, $7 \mathrm{~m}$ long $\times 6 \mathrm{~m}$ wide. Soybean seeds (Glycine max L. cv. Giza 111) were obtained from Field Crops Research Institute, Department of Leguminous Crops, Sakha, Agricultural Research Station, Egypt. Seeds of soybean were planted on 28 May 2019 and 29 May 2020 at the rate of $100 \mathrm{~kg} \mathrm{ha}^{-1}$. Plants were thinned to one plant per hill prior to first irrigation. Nitrogen fertilization was added as urea $(46.5 \% \mathrm{~N})$ at the rate of $18 \mathrm{~kg} \mathrm{~N} \mathrm{ha}^{-1}$. Phosphorus fertilization was applied as calcium superphosphate $15.5 \% \mathrm{P}_{2} \mathrm{O}_{5}$ at the rate of $80 \mathrm{~kg} \mathrm{P}_{2} \mathrm{O}_{5} \mathrm{ha}^{-1}$ prior to planting. Potassium fertilization applied at $\left(114 \mathrm{~kg} \mathrm{~K}_{2} \mathrm{O} \mathrm{ha}^{-1}\right)$ before planting.

\subsection{Soil Physicochemical Analysis}

Soil samples from the experimental site (0-30 cm depth) were collected by an auger and air-dried to estimate the physicochemical properties, which are as following: The texture of the experimental site was clayey, consisting of $28.25 \%$ sand, $24.37 \%$ silt and $47.38 \%$ clay with an initial $\mathrm{pH}$ of 8.23 (1:2.5 soil: water suspension) and an average exchange sodium percentage of $21.6 \%$. Total $\mathrm{N}$ and organic $\mathrm{C}$ contents were $9.92 \mathrm{mg} \mathrm{kg}^{-1}$ and $11.55 \mathrm{~g} \mathrm{~kg}^{-1}$, respectively [50]. The electrical conductivity of saturated soil-paste extract $(\mathrm{ECe})$ is $5.52 \mathrm{dS} \mathrm{m}^{-1}$. Soluble cations of $\mathrm{Ca}^{++}, \mathrm{Mg}^{++}, \mathrm{Na}^{+}$and $\mathrm{K}^{+}$were 9.43, 7.82, 37.34 and 0.38 meq $L^{-1}$, respectively [51].

\subsection{Treatments Preparation and Application}

\subsubsection{Seed Inoculation with Microbial Consortium}

Soybean seeds were sterilized with ethanol (70\%) and Clorox (10\%) for 3 min and bathed with autoclaved deionized water. Two microorganisms Bradyrhizobium japonicum (USDA 110) and Trichoderma harzianum were selected for their abilities to promote the growth of soybean [52]. Both strains were attained from Agricultural Microbiology Department, Soils, Water and Environment Research Institute (SWERI), Agricultural Research Centre (ARC), Egypt. Pure cultures of bacteria (B. japonicum) and fungi (T. harzianum) were 
routinely maintained on Yeast Extract Mannitol Broth (YEMB) medium and Potato Dextrose Broth (PDB) medium [53], respectively. The inoculation was prepared as peat-based inoculum, $10 \mathrm{~mL}$ of B. japonicum $\left(1 \times 108 \mathrm{CFU} \mathrm{mL}{ }^{-1}\right)$, and T. harzianum $\left(1 \times 10^{5}\right.$ spores $\left.\mathrm{mL}^{-1}\right)$ per $30 \mathrm{~g}$ of sterilized carrier and mixed with the soybean seeds before sowing using a sticking material and spread away from the direct sun over a plastic sheet for a short time prior planting.

\subsubsection{Beneficial and Micro-Elements Nanoparticles}

The nanoparticles of silicon dioxide $\left(\mathrm{SiO}_{2}\right.$ : $198 \mathrm{~nm}$ particle size) was provided by AL-Azhar University, Egypt, while the nanoparticles of zinc oxide (ZnO: $<100 \mathrm{~nm}$ particle size) was purchased from Sigma-Aldrich (St. Louis, USA). Nano-elements ( $\mathrm{Si}+\mathrm{Zn}$ ) were applied as a foliar application at $500 \mathrm{mg} \mathrm{L}^{-1}\left(250 \mathrm{mg} \mathrm{L}^{-1}\right.$ for each element) at 20,30, and 40 days after sowing (DAS), which was applied as a nutrient solution.

\subsection{Traits Measurements}

At 60 days after sowing, different plant samples were collected to determine the following variables: root length, nodules dry weight, the content of $\mathrm{Na}^{+}$and $\mathrm{K}^{+}$ions in the leaves, total chlorophyll, carotenoids, activity of antioxidant enzymes, malondialdehyde, total soluble sugars, proline, total free amino acids, and soluble proteins. In addition to leaf relative water content (LRWC), stomatal conductance, and electrolyte leakage (EL\%).

\subsubsection{Exchangeable Sodium \% (ESP)}

An auger was used to collect soil samples from the surface of the soil down to a depth of $40 \mathrm{~cm}$. Soil samples were air-dried and passed through a 2-mm mesh to determine the contents of $\mathrm{Na}^{+}, \mathrm{Ca}^{2+}$ and $\mathrm{Mg}^{2+}$ in paste extracts. The contents of $\mathrm{Na}^{+}, \mathrm{Ca}^{2+}$ and $\mathrm{Mg}^{2+}$ in paste extracts were determined using an Atomic Absorption Spectro-photometer (AAS 3300, Perkin Elmer Ltd., Beaconsfield, UK) to compute the soil sodium adsorption ratio (SAR). ESP was assessed according to the equation proposed by Seilsepour et al. [54]:

$$
\mathrm{ESP}=1.95+1.03 \times \operatorname{SAR}\left(\mathrm{R}^{2}=0.92\right)
$$

\subsubsection{Root Length, Nodules Dry Weight and Leaves Area}

Root samples were taken from each treatment type to estimate the root length $(\mathrm{cm})$ and nodules dry weight ( $\left.\mathrm{mg}_{\text {plant }}{ }^{-1}\right)$. The selected root samples were taken by soil sampling tube to $40 \mathrm{~cm}$ depth and sieving the soil through a $0.5 \mathrm{~mm}$ mesh. Nodules were detached from the roots, oven-dried at $70{ }^{\circ} \mathrm{C}$ and weighed. Total leaves area per plant $\left(\mathrm{dm}^{2}\right)$ was recorded by Leaf Area Meter (LA-3000A, LI-COR Inc., Lincoln, NE, USA).

\subsubsection{Potassium and Sodium Concentration}

Ten leaf samples were randomly collected from each experimental plot, washed with deionized water, and oven-dried for $48 \mathrm{~h}$ at $70{ }^{\circ} \mathrm{C}$. Oven-dried samples (approximately $0.5 \mathrm{~g}$ each) were heated for $5 \mathrm{~h}$ in a mixture of nitric acid and perchloric acid $(4: 1, v / v)$ in the presence of glass beads. The digested plant material was sieved before being diluted with de-ionized water, based on Chapman and Pratt [55] method. $\mathrm{Na}^{+}$and $\mathrm{K}^{+}$concentrations were estimated by the use of an AAS 3300 Atomic Absorption Spectrophotometer (Perkin Elmer Ltd.).

\subsubsection{Total Chlorophylls and Carotenoids Concentration}

Using the protocol described by Lichtenthaler [56], ten leaf samples were randomly taken from the top of the main stem in each treatment to determine total chlorophylls and carotenoids. Samples of leaf tissues $(0.1 \mathrm{~g}$ each) were ground and extracted in $5 \mathrm{~mL}$ of acetone at an $80 \%$ concentration. The extracted sap was centrifuged for $10 \mathrm{~min}$ at $13,000 \times g$, and the absorbance of the supernatant was measured at $663 \mathrm{~nm}, 645 \mathrm{~nm}$, and $470 \mathrm{~nm}$. 
Concentrations of total chlorophylls and carotenoids were calculated and expressed as $\mathrm{mg} \mathrm{g}^{-1}$ FW.

\subsubsection{Osmo-protectants and Protein Concentrations} Total Soluble Sugars (TSS)

Leaves fresh samples $(0.5 \mathrm{~g})$ were homogenized in $5 \mathrm{~mL}$ of $80 \%(v / v)$ ethanol and placed in a water bath at $80^{\circ} \mathrm{C}$ for $30 \mathrm{~min}$, followed by centrifugation at $10,000 \times g$ for $10 \mathrm{~min}$. The pellets were subjected to two further cycles using the same extraction protocol by $80 \%$ ethanol. The supernatants were collected to measure the total soluble sugars concentration based on Hendrix [57] protocol, using spectrophotometer at $620 \mathrm{~nm}$ wavelength, based on a glucose standard curve.

Proline

Concentrations of proline in $0.5 \mathrm{~g}$ leaf samples were determined using the methods described by Bates et al. [58]. Samples were homogenized in $10 \mathrm{~mL}$ of $3 \%(\mathrm{~m} / \mathrm{v})$ aqueous sulfosalicylic acid and centrifuged. Each $2 \mathrm{~mL}$ of supernatant was combined with $2 \mathrm{~mL}$ of acid ninhydrin reagent $(2 \mathrm{~g}$ ninhydrin in $30 \mathrm{~mL}$ glacial acetic acid and $20 \mathrm{~mL} 6 \mathrm{M}$ phosphoric acid) and $2 \mathrm{~mL}$ of glacial acetic acid. After the reaction mixture was boiled at $100{ }^{\circ} \mathrm{C}$ for $1 \mathrm{~h}$ and then cooled in an ice bath for $10 \mathrm{~min}$, the colour of the reaction mixture was extracted by adding $4 \mathrm{~mL}$ toluene and vortexed for $5 \mathrm{~min}$. The absorbance of coloured toluene was read at $520 \mathrm{~nm}$. Proline was estimated as $\mu \mathrm{mol} \mathrm{g}^{-1} \mathrm{FW}$ leaves.

\section{Free Amino Acid (FAA)}

Total free amino acids were extracted from $0.5 \mathrm{~g}$ of fresh leaf samples after the homogenization with $80 \%$ ethanol and centrifugation at $8000 \times g$ for $15 \mathrm{~min}$ at $4{ }^{\circ} \mathrm{C}$. Amino acids concentration was assayed in the supernatant using the ninhydrin reagent as described by Misra et al. [59]. The analysis was performed by the addition of ninhydrin reagent $(16 \%$ ninhydrin dissolved in citrate buffer, $\mathrm{pH} 5.0$ [26\% citric acid, and 58\% Na citrate]) to amino acid extract. The mixture was boiled for $20 \mathrm{~min}$ and then cooled to room temperature. Absorbance of the reaction was recorded at $570 \mathrm{~nm}$. Concentrations of the total free amino acids in leaves samples were calculated from the standard curve of L-leucine and presented as $\mathrm{mg} \mathrm{g}^{-1} \mathrm{FW}$.

\section{Total Soluble Protein (TSP)}

The concentration of soluble protein in leaves samples were estimated by the Brilliant Blue G-250 reagent with bovine serum albumin (BSA) as a standard based on the method described by Bradford [60].

\subsubsection{Activity of Antioxidant Enzymes (CAT, POD and SOD)}

Extracts of enzymatic antioxidant were made by freezing different leaves samples $(1 \mathrm{~g})$ in the liquid nitrogen to avoid proteolytic activity, then grinding with $5 \mathrm{~mL}$ of cold extraction buffer (0.1 M phosphate buffer, $\mathrm{pH} 7$, containing $0.5 \mathrm{mM}$ EDTA, and $2 \%[w / v]$ PVP), and centrifuging for $20 \mathrm{~min}$ at $10,000 \times g$ to use the supernatant as enzyme extract [11].

The activity of catalase (CAT), peroxidase (POD) and superoxide dismutase (SOD), were estimated at $25^{\circ} \mathrm{C}$, using a UV-160 A spectrophotometer (Shimadzu, Kyoto, Japan). The specific activity of CAT, POD, and SOD were estimated based on the protocols described by Aebi [61], Vetter et al. [62], and Beauchamp and Fridovich [63], respectively. The specific activity of the antioxidant enzymes is expressed as Unit $\mathrm{mg}^{-1}$ protein. Briefly, CAT activity in the samples was estimated based on tracking the $\mathrm{H}_{2} \mathrm{O}_{2}$ fading at $240 \mathrm{~nm}$ due to the catalytic activity of CAT in the samples. The activity of POD in the samples was determined by combining $100 \mu \mathrm{L}$ enzyme extract with $2.9 \mathrm{~mL} 50 \mathrm{mM}$ phosphate-citrate buffer ( $\mathrm{pH} 6.5), 0.03 \% \mathrm{H}_{2} \mathrm{O}_{2}$, and $0.1 \%$ ortho-phenylenediamine in the assay mixture. At $430 \mathrm{~nm}$, the change in absorbance was measured for $5 \mathrm{~min}$. SOD activity was determined based on the inhibition in the photoreduction of the dye nitroblue tetrazolium (NBT) by 
superoxide-formed radicals. The reaction mixture (consists of $100 \mu \mathrm{L}$ enzyme extract in $50 \mathrm{mM}$ phosphate buffer, $13 \mathrm{mM}$ methionine, $0.075 \mathrm{mM} \mathrm{NBT}, 0.10 \mathrm{mM}$ EDTA and $0.002 \mathrm{mM}$ riboflavin) was illuminated for $15 \mathrm{~min}$ in a light chamber. The absorbance of blue formazan formed dye was recorded directly at $550 \mathrm{~nm}$ in comparison to the sample free reaction mixture. The enzymatic unit of SOD has been defined as the amounts of the enzyme required to inhibit the reduction of chromogen by $50 \%$.

\subsubsection{Oxidative Damage Status \\ Malondialdehyde (MDA)}

The concentration of MDA in the leaves as an indicator for lipid peroxidation was performed according to the protocol described by Li et al. [64]. With a mortar and pestle, $0.5 \mathrm{~g}$ of fresh leaves was homogenized with $1 \mathrm{~mL} 0.1 \%(w / v)$ TCA solution. The mixture was centrifuged at $8000 \times g$ for $15 \mathrm{~min}$ at $4{ }^{\circ} \mathrm{C}$. For each $1 \mathrm{~mL}$ supernatant, $4 \mathrm{~mL}$ of $0.5 \%$ thiobarbituric acid (TBA) in 10\% TCA solution was added and incubated at $96{ }^{\circ} \mathrm{C}$ for $30 \mathrm{~min}$. After cooling, the absorbance (A) was recorded at $450 \mathrm{~nm}, 532 \mathrm{~nm}$, and $600 \mathrm{~nm}$. The MDA concentration was expressed as $\mathrm{nmol} \mathrm{g}^{-1} \mathrm{FW}$ based on the extinction coefficient of TBA $\left(1.53 \mathrm{mM}^{-1} \mathrm{~cm}^{-1}\right)$.

\section{Electrolyte Leakage Percentage (EL\%)}

The protocol described by Bajji, et al. [65] was used to estimate EL\%. Ten leaf discs were put in a $50 \mathrm{~mL}$ sealed tube including $20 \mathrm{~mL}$ distilled water and the electrical conductivity $\left(\mathrm{EC}_{0}\right)$ was measured by a conductivity meter (CM 100, John Reid and Associates, Chicago). The tubes were incubated in a water bath at $45^{\circ} \mathrm{C}$ for $30 \mathrm{~min}$, and the electrical conductivity $\left(\mathrm{EC}_{1}\right)$ was measured. The sample was heated at $100{ }^{\circ} \mathrm{C}$ for $10 \mathrm{~min}$, and the electrical conductivity $\left(\mathrm{EC}_{2}\right)$ was measured. The total leakage of inorganic ions was calculated according to the following equation: $\mathrm{EL} \%=\left[\left(\mathrm{EC}_{1}-\mathrm{EC}_{0}\right) / \mathrm{EC}_{2}\right] \times 100$.

\subsubsection{Plant Water Relations \\ Leaf Relative Water Content (LRWC)}

For the estimation of LRWC, the method of Weatherley [66] was used. Ten leaf discs with $10 \mathrm{~mm}$ in diameter were punched with a borer from a set of leaves into a reweighed sealed vial. After the fresh weight had been obtained, the discs were floated for $24 \mathrm{~h}$ on distilled water in covered Petri dishes kept at a low light intensity and room temperature until full turgid. The discs were surface dried, returned to the same vial, and reweighed to obtain the turgid weight. Finally, the leaf discs were oven-dried at $80^{\circ} \mathrm{C}$ to a constant weight and weighed again to obtain the dry weight. The LRWC on a percentage basis was calculated using the following equation:

$$
\text { LRWC }=\left(\frac{\text { Fresh weight }- \text { Dry weight }}{\text { Turgid weight }- \text { Dry weight }}\right) \times 100
$$

\section{Stomatal Conductance}

Stomatal conductance of fully expanded top leaf was determined between 10:00 and 13:00 using porometer apparatus (Model AP4, Delta-T Devices Ltd., Burwell, UK) and expressed as $\mathrm{mmol} \mathrm{H}_{2} \mathrm{O} \mathrm{m}^{-2} \mathrm{~s}^{-1}$.

\subsubsection{Seed Yield Related Traits and Nutritional Quality}

At maturity, the aboveground parts of soybean plants in each plot were harvested and were used as shoot samples for calculating the number of pods plant ${ }^{-1}$. Soybean seeds were separated from their pods to measure 100-seed weight $(\mathrm{g})$ and seed yield $\left(\mathrm{kg} \mathrm{ha}^{-1}\right)$. The protein content of soybean seeds was estimated via the micro-Kjeldahl method based on $\mathrm{N}$ content. Nitrogen was evaluated according to the method illustrated in A.O.A.C. [67], and the protein content was obtained by multiplying the nitrogen content by a conventional coefficient of 6.25. Total carbohydrate contents were extracted from dry powdered soybean 
seeds and estimated colorimetrically by the phenol-sulphuric acid method as described by Sadasivam and Manickam [68].

\subsection{Statistical Analysis}

The data of the two-year split-plot experiment were statistically analyzed separately according to the analysis of variance (ANOVA) procedure, using CoStat software (Package 6.45, CoHort, Monterey, CA, USA). The differences between the means were compared at $p<0.05$ using DMRT as posthoc pairwise comparisons [69]. Data are presented as means \pm SD. The comparisons of parallel coordinates were performed by JMP 16 (SAS Institute Inc., Cary, NC, USA).

\section{Conclusions}

Water stress and soil salinity together greatly lessen the plant growth and crop productivity, which effect on sensitive to moderate tolerant plants like soybean plant. Nevertheless, the coupled application of seed inoculation with PGPMs (Bradyrhizobium japonicum (USDA 110) and Trichoderma harzianum) and foliar application of Si-ZnNPs significantly mitigated the detrimental effects of water stress and soil salinity on soybean growth and productivity. Irrespective of water application duration $\left(\mathrm{IW}_{0}, \mathrm{IW}_{1}\right.$, and $\left.\mathrm{IW}_{2}\right)$, the co-application treatment of PGPMs and Si-ZnNPs caused the highest seed quality (i.e., protein and carbohydrate content) and highest yield-related traits (number of pods plant ${ }^{-1}$ and 100 -seed weight) of soybean plants grown under salt-affected soil in comparison to sole application of PGPMs or Si-ZnNPs and/or control plants. Such improvements were attributed to deeper root length, heavier nodules dry weight, higher leaf $\mathrm{K}^{+}$, further leaf soluble protein content, total soluble sugars, and antioxidant enzymes activity, as well as more augmented of physiological parameters (relative water content and stomatal conductance) while declined of leaf $\mathrm{Na}^{+}$, electrolyte leakage, proline content, and free amino acids, as well as ESP, were attained when the coupled treatment was added compared to the sole treatment of PGPMs or Si-ZnNPs under longer irrigation intervals $\left(\mathrm{IW}_{1}\right.$ and $\left.\mathrm{IW}_{2}\right)$. Our study proved that the coupled application of PGPMs and Si-ZnNPs has multiple benefits for agricultural sustainability, especially in arid and semi-arid zones.

Author Contributions: Conceptualization, E.M.H., H.S.O. and A.E.-D.O.; methodology, M.E., U.A.A.E.-R. and A.M.A.E.-M.; software, S.M.G.; validation, M.E., A.E.-D.O. and U.A.A.E.-R.; formal analysis, E.M.H. and A.M.A.E.-M.; investigation, E.M.H., H.S.O. and S.M.G.; resources, M.E., U.A.A.E.-R. and A.E.-D.O.; data curation, H.S.O., A.E.-D.O. and S.M.G.; writing-original draft preparation, E.M.H. and H.S.O.; writing-review and editing, E.M.H. and H.S.O.; visualization, A.M.A.E.-M. and U.A.A.E.-R.; supervision, E.M.H. and H.S.O.; funding acquisition, M.E. All authors have read and agreed to the published version of the manuscript.

Funding: This research received no external funding.

Acknowledgments: This work was supported by the Deanship of Scientific Research at King Khalid University under Grant number R.G.P. 1/112/42. All the authors are grateful the support provided by the following institutions: Faculty of Agriculture, Kafrelsheikh University, Egypt; Soils, Water and Environment Research Institute (SWERI), Agriculture Research Center (ARC), Egypt; and Scientific Research Sector of Ain Shams University, Egypt.

Conflicts of Interest: The authors declare no conflict of interest.

\section{References}

1. Munns, R.; Gilliham, M. Salinity tolerance of crops-What is the cost? New Phytol. 2015, 208, 668-673. [CrossRef]

2. Negrão, S.; Schmöckel, S.M.; Tester, M. Evaluating physiological responses of plants to salinity stress. Ann. Bot 2017, 119, 1-11. [CrossRef] [PubMed]

3. Parihar, P.; Singh, S.; Singh, R.; Singh, V.P.; Prasad, S.M. Effect of salinity stress on plants and its tolerance strategies: A review. Environ. Sci. Pollut. Res. 2014, 22, 4056-4075. [CrossRef] [PubMed]

4. Munns, R.; Tester, M. Mechanisms of salinity tolerance. Annu. Rev. Plant. Biol. 2008, 59, 651-681. [CrossRef] 
5. Hafez, E.M.; Kheir, A.M.S.; Badawy, S.A.; Rashwan, E.; Farig, M.; Osman, H.S. Differences in physiological and biochemical attributes of wheat in response to single and combined salicylic acid and biochar subjected to limited water irrigation in saline sodic soil. Plants 2020, 9, 1346. [CrossRef] [PubMed]

6. Parida, A.K.; Das, A.B. Salt tolerance and salinity effects on plants: A review. Ecotoxic. Environ. Safety 2005, 60, 324-349. [CrossRef]

7. Salim, B.B.M.; Hikal, M.S.; Osman, H.S. Ameliorating the deleterious effects of saline water on the antioxidants defense system and yield of eggplant using foliar application of zinc sulphate. Ann. Agric. Sci. 2019, 64, 244-251. [CrossRef]

8. Osman, H.S.; Salim, B.B. Improving yield and quality of kohlrabi stems growing under $\mathrm{NaCl}$ salinity using foliar application of urea and seaweed extract. J. Hort. Sci. Ornament. Plant. 2016, 8, 149-160.

9. Osman, H.S.; Salim, B.B.M. Enhancing antioxidants defense system of snap bean under $\mathrm{NaCl}$ salinity using foliar application of salicylic acid, spermidine and glycine betaine. Am. Eurasian J. Agric. Environ. Sci. 2016, 16, 1200-1210.

10. Wang, B.; Zhang, J.; Pei, D.; Yu, L. Combined effects of water stress and salinity on growth, physiological, and biochemical traits in two walnut genotypes. Physiol. Plant. 2021, 172, 176-187. [CrossRef]

11. Osman, H.S. Enhancing antioxidant-yield relationship of pea plant under drought at different growth stages by exogenously applied glycine betaine and proline. Ann. Agric. Sci. 2015, 60, 389-402. [CrossRef]

12. Hafez, E.; Omara, A.E.D.; Ahmed, A. The coupling effects of plant growth promoting rhizobacteria and salicylic acid on physiological modifications, yield traits, and productivity of wheat under water deficient conditions. Agronomy 2019, 9, 524. [CrossRef]

13. Munns, R. Comparative physiology of salt and water stress. Plant. Cell Environ. 2002, 25, 239-250. [CrossRef] [PubMed]

14. Sahin, U.; Ekinci, M.; Ors, S.; Turan, M.; Yildiz, S.; Yildirim, E. Effects of individual and combined effects of salinity and drought on physiological, nutritional and biochemical properties of cabbage (Brassica oleracea var. capitata). Sci. Hortic. 2018, 240, 196-204. [CrossRef]

15. Araújo, S.S.; Beebe, S.; Crespi, M.; Delbreil, B.; González, E.M.; Gruber, V.; Lejeune-Henaut, I.; Link, W.; Monteros, M.J.; Prats, E.; et al. Abiotic stress responses in legumes: Strategies used to cope with environmental challenges. Crit. Rev. Plant. Sci. 2015, 34, 237-280. [CrossRef]

16. Pagano, M.C.; Miransari, M. The importance of soybean production worldwide. In Abiotic and Biotic Stresses in Soybean Production; Miransari, M., Ed.; Academic Press: San Diego, CA, USA, 2016; pp. 1-26.

17. Han, H.S.; Lee, K.D. Physiological responses of soybean-inoculation of Bradyrhizobium japonicum with PGPR in saline soil conditions. Res. J. Agric. Biol. Sci. 2005, 1, 216-221.

18. Maas, E.V.; Grattan, S.R. Crop yields as affected by salinity. In Agricultural Drainage; Skaggs, R.W., van Schilfgaarde, J., Eds.; Wiley: Hoboken, NJ, USA, 1999; pp. 55-108.

19. Ku, Y.-S.; Au-Yeung, W.-K.; Yung, Y.-L.; Li, M.-W.; Wen, C.-Q.; Liu, X.; Lam, H.-M. Drought stress and tolerance in soybean. In A Comprehensive Survey of International Soybean Research-Genetics, Physiology, Agronomy and Nitrogen Relationships; Board, J.E., Ed.; IntechOpen: London, UK, 2013. [CrossRef]

20. Liu, F.; Jensen, C.R.; Andersen, M.N. Drought stress effect on carbohydrate concentration in soybean leaves and pods during early reproductive development: Its implication in altering pod set. Field Crops Res. 2004, 86, 1-13. [CrossRef]

21. Hafez, E.; Farig, M. Efficacy of salicylic acid as a cofactor for ameliorating effects of water stress and enhancing wheat yield and water use efficiency in saline soil. Int. J. Plant. Prod. 2019, 13, 163-176. [CrossRef]

22. Hafez, E.M.; Alsohim, A.S.; Farig, M.; Omara, A.E.-D.; Rashwan, E.; Kamara, M.M. Synergistic effect of biochar and plant growth promoting rhizobacteria on alleviation of water deficit in rice plants under salt-affected soil. Agronomy 2019, 9, 847. [CrossRef]

23. Hafez, E.M.; Omara, A.E.D.; Alhumaydhi, F.A.; El-Esawi, M.A. Minimizing hazard impacts of soil salinity and water stress on wheat plants by soil application of vermicompost and biochar. Physiol. Plant. 2020, 1-16. [CrossRef]

24. Hafez, E.M.; Osman, H.S.; Gowayed, S.M.; Okasha, S.A.; Omara, A.E.-D.; Sami, R.; Abd El-Monem, A.M.; Abd El-Razek, U.A. Minimizing the adversely impacts of water deficit and soil salinity on maize growth and productivity in response to the application of plant growth-promoting rhizobacteria and silica nanoparticles. Agronomy 2021, 11, 676. [CrossRef]

25. Hafez, E.M.; Osman, H.S.; El-Razek, U.A.A.; Elbagory, M.; Omara, A.E.-D.; Eid, M.A.; Gowayed, S.M. Foliar-applied potassium silicate coupled with plant growth-promoting rhizobacteria improves growth, physiology, nutrient uptake and productivity of faba bean (Vicia faba L.) irrigated with saline water in salt-affected soil. Plants 2021, 10, 894. [CrossRef] [PubMed]

26. Mendes, R.; Garbeva, P.; Raaijmakers, J.M. The rhizosphere microbiome: Significance of plant beneficial, plant pathogenic, and human pathogenic microorganisms. FEMS Microbiol. Rev. 2013, 37, 634-663. [CrossRef] [PubMed]

27. Olanrewaju, O.S.; Glick, B.R.; Babalola, O.O. Mechanisms of action of plant growth promoting bacteria. World J. Microbiol. Biotechnol. 2017, 33, 197. [CrossRef] [PubMed]

28. Ma, Y.; Dias, M.C.; Freitas, H. Drought and salinity stress responses and microbe-induced tolerance in plants. Front. Plant. Sci. 2020, 11. [CrossRef]

29. Kumar, A.; Verma, J.P. Does plant-Microbe interaction confer stress tolerance in plants: A review? Microbiol. Res. 2018, 207, 41-52. [CrossRef]

30. Egamberdieva, D.; Wirth, S.J.; Alqarawi, A.A.; Abd Allah, E.F.; Hashem, A. Phytohormones and beneficial microbes: Essential components for plants to balance stress and fitness. Front. Microbiol. 2017, 8, 2104. [CrossRef]

31. Solyman, S.N.; Abdel-Monem, M.; Abou-Taleb, K.; Osman, H.S.; El-Sharkawy, R.M. Production of plant growth regulators by some fungi isolated under salt stress. South Asian J. Res. Microbiol. 2019, 3, 1-10. [CrossRef] 
32. Masciarelli, O.; Llanes, A.; Luna, V. A new PGPR co-inoculated with Bradyrhizobium japonicum enhances soybean nodulation. Microbiol. Res. 2014, 169, 609-615. [CrossRef] [PubMed]

33. Egamberdieva, D.; Wirth, S.; Jabborova, D.; Räsänen, L.A.; Liao, H. Coordination between Bradyrhizobium and Pseudomonas alleviates salt stress in soybean through altering root system architecture. J. Plant. Interact. 2017, 12, 100-107. [CrossRef]

34. Hermosa, R.; Viterbo, A.; Chet, I.; Monte, E. Plant-beneficial effects of Trichoderma and of its genes. Microbiology 2012, 158, 17-25. [CrossRef] [PubMed]

35. Mona, S.A.; Hashem, A.; Abd_Allah, E.F.; Alqarawi, A.A.; Soliman, D.W.K.; Wirth, S.; Egamberdieva, D. Increased resistance of drought by Trichoderma harzianum fungal treatment correlates with increased secondary metabolites and proline content. J. Integrat. Agric. 2017, 16, 1751-1757. [CrossRef]

36. Marra, R.; Lombardi, N.; d'Errico, G.; Troisi, J.; Scala, G.; Vinale, F.; Woo, S.L.; Bonanomi, G.; Lorito, M. Application of Trichoderma strains and metabolites enhances soybean productivity and nutrient content. J. Agric. Food Chemist. 2019, 67, 1814-1822. [CrossRef]

37. Broadley, M.; Brown, P.; Cakmak, I.; Rengel, Z.; Zhao, F. Function of nutrients: Micronutrients. In Marschner's Mineral Nutrition of Higher Plants, 3rd ed.; Marschner, P., Ed.; Academic Press: San Diego, CA, USA, 2012; pp. 191-248.

38. Kheir, A.M.S.; Abouelsoud, H.M.; Hafez, E.M.; Ali, O.A.M. Integrated effect of nano-Zn, nano-Si, and drainage using crop straw-filled ditches on saline sodic soil properties and rice productivity. Arab. J. Geosci. 2019, 12, 471. [CrossRef]

39. Osman, H.S.; Abd El-Gawad, H.G. Impact of stimulators of amylase activity $\left(\mathrm{GA}_{3}, \mathrm{CaCl}_{2}\right)$ and protein synthesis $(\mathrm{ZnSO} 4)$ on yield, quality and reducing seed abortion of pea plant. Res. J. Agric. Biol. Sci. 2013, 9, 381-390.

40. Batista, P.F.; Müller, C.; Merchant, A.; Fuentes, D.; Silva-Filho, R.d.O.; da Silva, F.B.; Costa, A.C. Biochemical and physiological impacts of zinc sulphate, potassium phosphite and hydrogen sulphide in mitigating stress conditions in soybean. Physiol. Plant. 2020, 168, 456-472. [CrossRef] [PubMed]

41. Youssif, N.E.E.; Osman, H.S.M.; Salama, Y.A.M.; Zaghlool, S.A.M. Effect of rice straw and applications of potassium silicate, potassium humate and seaweed extract on growth and some macronutrients of sweet pepper plants under irrigation deficit. Arab Univ. J. Agric. Sci. 2018, 26, 755-773. [CrossRef]

42. Seleiman, M.F.; Refay, Y.; Al-Suhaibani, N.; Al-Ashkar, I.; El-Hendawy, S.; Hafez, E.M. Integrative effects of rice-straw biochar and silicon on oil and seed quality, yield and physiological traits of Helianthus annuus L. grown under water deficit stress. Agronomy 2019, 9, 637. [CrossRef]

43. Yeo, A.R.; Flowers, S.A.; Rao, G.; Welfare, K.; Senanayake, N.; Flowers, T.J. Silicon reduces sodium uptake in rice (Oryza sativa L.) in saline conditions and this is accounted for by a reduction in the transpirational bypass flow. Plant. Cell Environ. 1999, 22, 559-565. [CrossRef]

44. Liu, R.; Lal, R. Potentials of engineered nanoparticles as fertilizers for increasing agronomic productions. Sci. Total Environ. 2015, 514, 131-139. [CrossRef] [PubMed]

45. Boiero, L.; Perrig, D.; Masciarelli, O.; Penna, C.; Cassán, F.; Luna, V. Phytohormone production by three strains of Bradyrhizobium japonicum and possible physiological and technological implications. Appl. Microbiol. Biotech. 2007, 74, 874-880. [CrossRef]

46. Oliveira, C.M.; Almeida, N.O.; da Rocha, M.R.; Rezende, M.H.; Carneiro, R.G.d.S.; Ulhoa, C.J. Anatomical changes induced by isolates of Trichoderma spp. in soybean plants. PLoS ONE 2020, 15, e0242480. [CrossRef] [PubMed]

47. Pal, V.; Singh, G.; Dhaliwal, S.S. Symbiotic parameters, growth, productivity and profitability of chickpea as influenced by zinc sulphate and urea application. J. Soil Sci. Plant. Nutr. 2020, 20, 738-750. [CrossRef]

48. Tripathi, P.; Na, C.-I.; Kim, Y. Effect of silicon fertilizer treatment on nodule formation and yield in soybean (Glycine max L.). Eur. J. Agron. 2021, 122, 126172. [CrossRef]

49. Osman, H.S.; Salim, B.B.M. Influence of exogenous application of some phytoprotectants on growth, yield and pod quality of snap bean under $\mathrm{NaCl}$ salinity. Ann. Agric. Sci. 2016, 61, 1-13. [CrossRef]

50. McKeague, J.A. Manual on Soil Sampling and Methods of Analysis, 2nd ed.; Canadian Society of Soil Science: Ottawa, ON, Canada, $1978 ; 212 p$.

51. Mclean, E.O. Soil pH and Lime Requirement. In Methods of Soil Analysis; Page, A.L., Ed.; ASA-SSSA; Soil Science Society of America: Madison, WI, USA, 1983; pp. 199-224.

52. El-Nahrawy, S.; Elbagory, M.; Omara, A.E.-D. Biocompatibility effect of Bradyrhizobium japonicum and Trichoderma strains on growth, nodulation and physiological traits of soybean (Glycine max 1.) under water deficit conditions. J. Adv. Microbiol. 2020, 20, 52-66. [CrossRef]

53. Atlas, R.M. Handbook of Microbiological Media, 4th ed.; CRC press: Boca Raton, FL, USA, 2010; 2040p.

54. Seilsepour, M.; Rashidi, M.; Khabbaz, B.G. Prediction of soil exchangeable sodium percentage based on soil sodium adsorption ratio. Am. Eurasian J. Agric. Environ. Sci. 2009, 5, 1-4.

55. Chapman, H.D.; Pratt, P.F. Methods of Analysis for Soils, Plants and Waters. Soil Sci. 1962, 93, 68. [CrossRef]

56. Lichtenthaler, H.K. Chlorophylls and carotenoids: Pigments of photosynthetic biomembranes. In Methods in Enzymology; Academic Press: San Diego, CA, USA, 1987; Volume 148, pp. 350-382.

57. Hendrix, D.L. Rapid extraction and analysis of nonstructural carbohydrates in plant tissues. Crop. Sci. 1993, 33, 1306-1311. [CrossRef]

58. Bates, L.S.; Waldren, R.P.; Teare, I.D. Rapid determination of free proline for water-stress studies. Plant. Soil 1973, 39, $205-207$. [CrossRef] 
59. Misra, P.S.; Mertz, E.T.; Glover, D.V. Studies on corn proteins. VIII. Free amino acid content of opaque-2 double mutants. Cereal Chem. 1975, 52, 844-848.

60. Bradford, M.M. A rapid and sensitive method for the quantitation of microgram quantities of protein utilizing the principle of protein-dye binding. Analyt. Biochem. 1976, 72, 248-254. [CrossRef]

61. Aebi, H. Catalase in vitro. In Methods in Enzymology; Academic Press: San Diego, CA, USA, 1984; pp. 121-126.

62. Vetter, J.L.; Steinberg, M.P.; Nelson, A.I. Enzyme assay, quantitative determination of peroxidase in sweet corn. J. Agric. Food Chemist. 1958, 6, 39-41. [CrossRef]

63. Beauchamp, C.; Fridovich, I. Superoxide dismutase: Improved assays and an assay applicable to acrylamide gels. Analyt. Biochem. 1971, 44, 276-287. [CrossRef]

64. Li, Q.-T.; Yeo, M.H.; Tan, B.K. Lipid peroxidation in small and large phospholipid unilamellar vesicles induced by water-soluble free radical sources. Biochem. Biophysic. Res. Communic. 2000, 273, 72-76. [CrossRef] [PubMed]

65. Bajji, M.; Kinet, J.-M.; Lutts, S. The use of the electrolyte leakage method for assessing cell membrane stability as a water stress tolerance test in durum wheat. Plant. Growth Regul. 2002, 36, 61-70. [CrossRef]

66. Weatherley, P.E. Studies in the water relations of the cotton plant. I. The field measurement of water deficits in leaves. New Phytol. 1950, 49, 81-97. [CrossRef]

67. A.O.A.C. Official Methods of Analysis of AOAC International, 18th ed.; Association of Official Analytical Chemists: Washington, DC, USA, 2005.

68. Sadasivam, S.; Manickam, A. Biochemical Methods, 3rd ed.; New Age International Publishers: New Delhi, India, 2010.

69. Duncan, D.B. Multiple range and multiple F tests. Biometrics 1955, 11, 1-42. [CrossRef] 